\section{LITERASI KEAGAMAAN DAN KARAKTER PESERTA DIDIK}

Ide penyederhanaan kurikulum pendidikan dasar dan menengah yang fokus pada tiga hal yakni literasi, numerasi dan karakter pada dasarnya dalam kerangka peningkatan mutu pendidikan. Harapannya agar peserta didik kuat dalam kemampuan menganalisis dan menyelesaikan problem masa depan dengan berbasis pada data (literasi). Selain itu, peserta didik juga diharapkan memiliki karakter yang baik. Isi buku ini memang tidak secara langsung terkait dengan ide penyederhanaan kurikulum tersebut, tetapi artikel-artikel dalam buku ini yang berkaitan dengan literasi dan karakter bisa menjadi refleksi atas peningkatan mutu pendidikan khususnya. Buku dapat menjadi bahan untuk merespon inovasi pendidikan yang dicanangkan oleh Kementerian Pendidikan dan Kebudayaan.

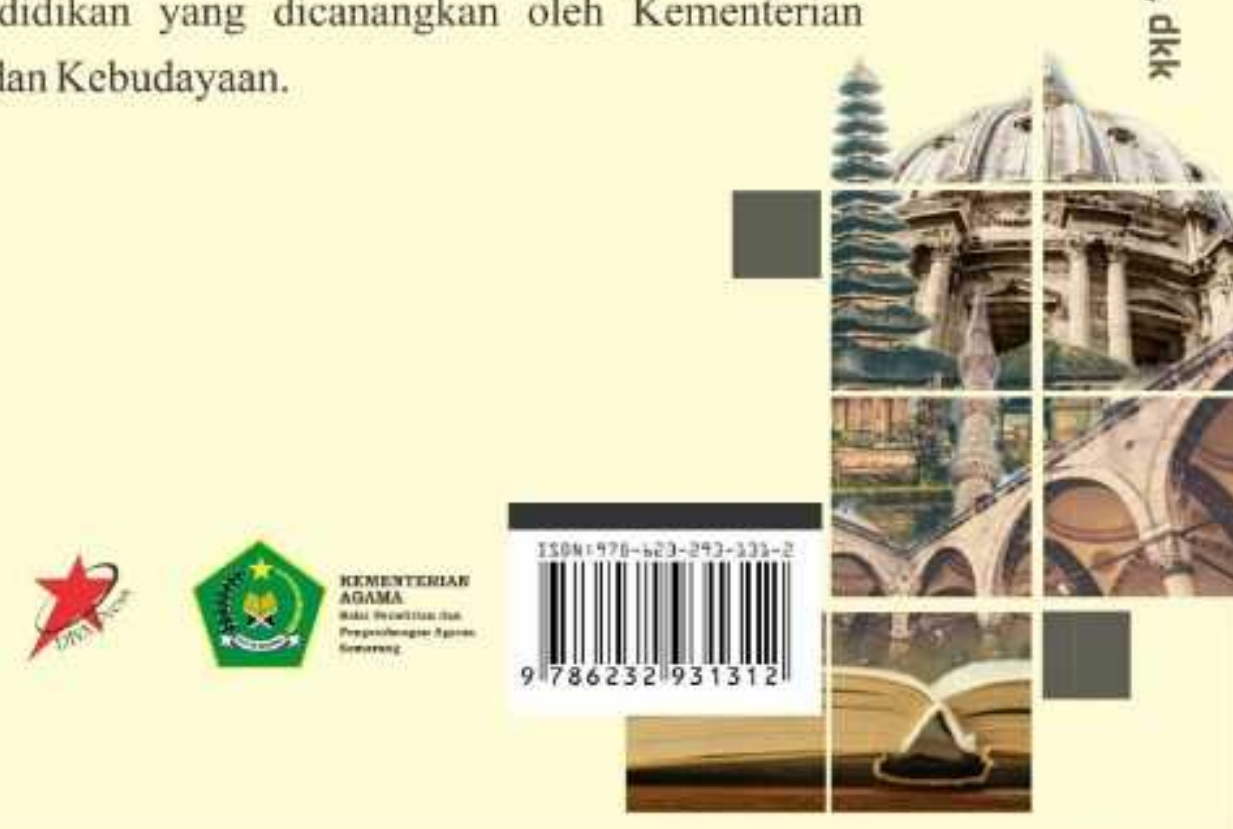

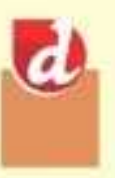

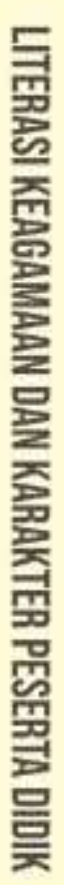

Editor: Aji Sofanudin dan Ahmad Muntakhib

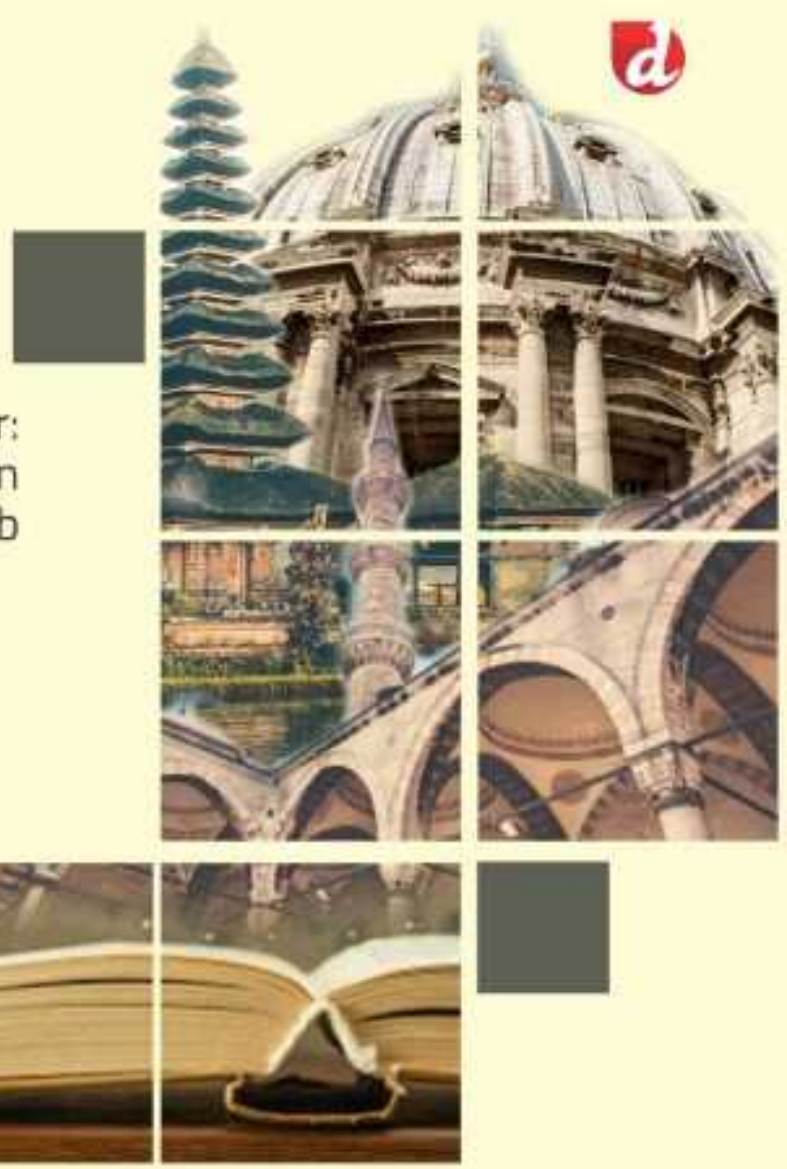

\section{LITERASI KEAGAMAAN DAN KARAKTER PESERTA DIDIK}




\section{Aji Sofanudin, dkk}

\section{LITERASI KEAGAMAAN DAN KARAKTER PESERTA DIDIK}




\section{LITERASI KEAGAMAAN DAN KARAKTER PESERTA DIDIK}

Penulis: Aji Sofanudin, dkk

Editor: Aji Sofanudin dan Ahmad Muntakhib

Tata Sampul: Quella

Tata Isi: Mohammad Hasib

Pracetak: Antini, Dwi, Wardi

Cetakan Pertama, November 2020

Penerbit

DIVA Press

(Anggota IKAPI)

Sampangan Gg. Perkutut No.325-B

Jl. Wonosari, Baturetno

Banguntapan Yogyakarta

Telp: (0274) 4353776, 081804374879

Fax: (0274) 4353776

E-mail:redaksi_divapress@yahoo.com sekred2.divapress@gmail.com

Blog: www.blogdivapress.com

Website: www.divapress-online.com

Bekerjasama dengan Balai Penelitian dan Pengembangan Agama Semarang

Jl. Untung Suropati Kav. 70 Bambankerep, Ngaliyan, Semarang

(KP) 50185, Telp. (024) 7601327, Fax. (024) 7611386

Email: bla_semarang@kemenag.go.id

Perpustakaan Nasional: Katalog Dalam Terbitan (KDT)

Sofanudin, Aji, dkk

Literasi Keagamaan dan Karakter Peserta Didik/Aji Sofanudin, dkk; editor, Aji Sofanudin dan Ahmad Muntakhib-cet. 1-Yogyakarta: DIVA Press, 2020

viii +312 hlmn; 15,5 × $24 \mathrm{~cm}$

ISBN 978-623-293-131-2

I. Judul

II. Aji Sofanudin dan Ahmad Muntakhib 


\section{DAFTAR ISI}

Sambutan Kepala Balai Penelitian dan Pengembangan

Agama Semarang ................................................ iii

Pengantar Editor......................................................

Prolog

Literasi, Numerasi, dan Survei Karakter (Aji Sofanudin)..... 3

\section{Bagian I Literasi Keagamaan}

Praktik Literasi Keagamaan Pada Siswa Madrasah

Aliyah Berbasis Pesantren (Mustolehudin) .................... 17

Literatur Keagamaan Pada SMA di Bawah Yayasan

Keagamaan Katolik (Umi Masfiah)................................. 49

Praktik Literasi Keagamaan Mahasiswa Uin Sunan

Ampel Surabaya (Moch Lukluil Maknun) ........................ 83

\section{Bagian II Karakter Peserta Didik}

Indeks Karakter Peserta Didik di Provinsi Bali

(Aji Sofanudin dan Wahab)

Integrasi Pendidikan Karakter Peserta Didik

di Kabupaten Pasuruan (Ahmad Muntakhib)

143 
Indeks Karakter Peserta Didik di Kabupaten

Pamekasan (Nugroho Eko Atmanto)

Survei Karakter Peserta Didik di Kabupaten Tuban

dan Jombang (Mulyani Mudis Taruna dan Abdul Rohman) 191

Potret Karakter Peserta Didik di Kabupaten Kediri

dan Jombang (A.M. Wibowo)

223

Survei Karakter Peserta Didik di Kabupaten Kediri dan Malang (Wahab)

Epilog

Tantangan Pendidikan Karakter dan Literasi

(Ahwan Fanani)

271

Bibliografi

283

Biodata Penulis. 301

Indeks 


\title{
PRAKTIK LITERASI KEAGAMAAN MAHASISWA UIN SUNAN AMPEL SURABAYA
}

\author{
Moch Lukluil Maknun
}

\section{Pendahuluan}

Kajian literasi sudah berkembang luas dan beragam. Literasi dapat ditinjau dari literasi dasar, membaca, menulis, media, dan lain sebagainya. Kajian literasi lokal dan kasuistik juga sudah banyak dilakukan, tetapi kajian lokal dan fokus yang mendalam sulit dijumpai. Apa pun bentuk literasi yang sudah dikaji, tetaplah inti utamanya adalah kemampuan membaca dan menulis (Primadesi 2018; Suwarto 2018; Antoro 2017; Kemendikbud 2016). Kajian ini melihat fondasi dasar literasi tersebut dengan lebih mendalam, yaitu melihat praktik literasi baca-tulis mahasiswa kemudian menggali potensi dan peluang untuk mewujudkan kampus literat.

Kajian literasi terbaru yang cukup bersinggungan dengan kajian ini adalah kajian terkait "Literatur Keislaman Generasi Milenial" dari berbagai penulis yang sudah disusun dalam bunga rampai terbitan Pascasarjana UIN Sunan Kalijaga (Hasan et al. 2018). Di antara temuan menarik yang tertuang dalam kajian ini sebagai berikut. Suhadi dalam kesimpulan kajian bacaan PAI di SMA dan Perguruan Tinggi (PT) menyatakan bahwa: 1) kurikulum PAI sudah inklusif, tetapi tidak sepenuhnya solid; 2) kualitas literatur PAI di PT umumnya memprihatinkan, dalam arti kemasan kurang menarik dan kualitas akademiknya rendah; 3) perlunya pemilihan konsep-konsep teologi yang tidak kontroversial 4) penyajian buku PAI SMA lebih menarik dibanding PT; dan 5) 
perlunya mewaspadai referensi yang dipakai kontributor PAI (Suhadi 2018).

Ikhwan menyatakan bahwa aktor-aktor kelompok Islamis yang muncul setelah lengsernya Orde Baru 1998 berlomba-lomba memenangkan opini publik. Wacana Islamisme masa ini (disebut Islamisme populer) mengemas unsur-unsur Islamis dengan halus. Beberapa literasi yang diproduksi oleh aktor-aktor ini dapat memberikan ilustrasi dan imajinasi model hidup muslim yang taat, dengan tetap dapat menikmati simbol kemodernan, sehingga digemari oleh para generasi muda. Meskipun demikian, umumnya penulis Islamis populer tidak memiliki hubungan intelektual yang kuat dengan tradisi intelektual ulama, melainkan membangun hubungan khusus dengan pembaca dalam gaya bahasa komunikatif, memotivasi, dan tidak hierarkis. Keberhasilan mereka lebih dipengaruhi oleh kemampuan mentransformasikan ajaran agama ke dalam bahasa populer masa kini, yaitu keluar dari gaya bahasa teks agama klasik. Sasaran bidikan pengaruh ide mereka bukanlah pembaca dari kelompok muslim terpelajar atau ulama, melainkan para pembaca baru potensial terutama generasi muda (Ikhwan 2018).

Bacaan islamisme populer juga lekat dengan salafisme di Indonesia yang muncul sejak tumbangnya Orde Baru. Penyebab lapak literatur keislaman baru ini laris oleh pembaca generasi muda, di antaranya diawali dari ketidakpuasan terhadap Pendikikan Agama Islam yang diperoleh di kelas, jam terbatas, dan penyampaian guru atau dosen yang membosankan, serta rasa ingin tahu yang besar terhadap Islam (Ichwan 2018).

Tren awal literatur Islamis di Indonesia yang beredar, dibaca, dan didiskusikan oleh para aktivis Muslim di kampus non-agama didominasi oleh terjemahan karya ideologis Islamis ke dalam bahasa Indonesia. Pergeseran literatur keislaman di Indonesia dari literatur klasik ke kontemporer juga mengarah ke majalah-majalah Islami. Literatur-literatur ini di antaranya dapat diterima dengan baik karena dianggap mampu mengapropriasi ide-ide para tokoh Islamis (seperti Sayyid Qutb, Hasan Al-Banna, Al-Maududi, Ali Syariati, dan Taqiyyudin An-Nabhani) ke dalam konteks baru yang dihadapi masyarakat Indonesia. Jika di tahun 80-an dan 90-an literatur Islamis yang memikat anak muda Muslim adalah yang bercorak ideologis, maka pada tahun 2000an adalah yang bercorak 
motivasi, pengembangan diri, dan story telling yang dihadirkan dalam bentuk novel, tulisan populer, dan komik (Kailani 2018).

Proses adaptasi ideologi Islamisme yang mempertemukan dinamika transnasional Timur Tengah dengan ruang lokal baru (Indonesia) melahirkan dinamika yang beragam. Demikian pula proses pemindahan ideologi ke dalam literaturnya. Dinamika literatur di atas lokal menandai transmisi dan transformasi ideologis Islamisme di pusat Timur Tengah dan gerakan-gerakan yang menyertainya ke wilayah pinggiran yang dihuni oleh mayoritas muslim dunia. Melalui proses ini lahirlah ideologi seperti Tarbiyah dan Ikhwanul Muslimin di Mesir, Tahriri dan gerakan perjuangan di Palestina, serta Salafi dan Wahabi di Saudi. Ada dua hal mendasar yang selalu tampak dalam struktur argumen literatur Islamisme lokal; pertama adalah usaha menghubungkan isu-isu yang dibahas dengan sumber asal atau fenomena global yang lebih luas; kedua adalah upaya membangun posisi diametrikal dengan fenomena sosial, budaya, gerakan, atau pemikiran seseorang atau kelompok (Rafiq 2018).

Meskipun penyebaran literatur berideologi Islamisme cukup gencar di kalangan siswa dan mahasiswa, tetapi daya tolak terhadapnya pun cukup tinggi. Hal inilah yang memberikan harapan masa depan keislaman moderat. Beberapa upaya mengahadapi tantangan Islamisme oleh kaum moderat sudah terwujud dalam buku-buku lembar kerja siswa (LKS) yang misalnya menekankan toleransi, buku-buku PAI karya asosiasi dosen di perguruan tinggi juga menekankan dan mempromosikan Islam moderat dan pluralisme (Burdah 2018).

Berbeda dengan kajian literatur keislaman generasi milenial di atas, objek kajian ini lebih pada praktik literasi, yaitu literasi yang dimaknai sebagai keterampilan yang berpusat pada teks terutama membaca dan menulis (Iswanto et al. 2019). Dengan kata lain, kajian praktik literasi ini mengamati ragam teks yang dibaca, tujuan, lokasi, serta partisipasi mahasiswa terhadap aktivitas literasi, dengan kata lain menggali bentuk-bentuk literasi yang ada di kampus UINSA.

Ada sembilan aspek praktik literasi membaca dan menulis yang pernah dicetuskan. Aspek-aspek tersebut adalah: 1) topik atau isu, 2) gaya dan konvensi, 3) mode dan teknologi, 4) tujuan, 
5) fleksibilitas dan kendala, 6) aksi dan proses, 7) audiens, 8) peran dan identitas, serta 9) interaksi dan kolaborasi (Edwards 2012; Iswanto et al. 2019).

Kajian ini merupakan bagian dari kajian multikasus Praktik Literasi Mahasiswa Universitas Islam Negeri di Yogyakarta, Jawa Tengah, Jawa Timur, Nusa Tenggara Barat, dan Kalimantan Selatan (Iswanto et al. 2019). Berbeda dengan hasil penelitian yang sudah dibukukan sebelumnya yang merangkum temuan dari enam Universitas Islam Negeri tersebut, kajian ini hanya memfokuskan objek pada kampus UIN Sunan Ampel Surabaya. Jika kajian Iswanto dkk. tersebut memfokuskan pada kondisi infrastruktur literasi dan pemanfaataannya oleh mahasiswa, kemudian praktik literasi mahasiswa, maka kajian ini akan lebih spesifik pada objek kajiannya serta usaha memberikan beberapa rumusan potensi dan peluang mewujudkan kampus UINSA yang literat.

Rentang waktu yang telah digunakan untuk melakukan kajian ini dari awal perencanaan, penggalian data, hingga analisis data kurang lebih dua bulan (Mei-Juni 2018). Partisipan dalam pengumpulan kajian ini ditentukan secara purposif, yaitu kepada mahasiswa-mahasiswa yang terhimpun dalam Himpunan Mahasiswa Jurusan (HMJ) yang merupakan representasi dari mahasiswa pada umumnya dan lebih sesuai untuk ikut merumuskan praktik literasi yang ada di kampusnya. Data yang dikumpulkan akan diklasifikasi hingga mencapai kejenuhan data (Creswell 2007; Iswanto et al. 2019).

Secara kualitatif teknik pengumpulan data ini memanfaatkan observasi, wawancara, studi dokumen, kuesioner, serta focus group discussion yang difokuskan pada penggalian jawaban dari kedua rumusan masalah di atas. Observasi dilakukan untuk menangkap gambaran lokasi literasi seperti perpustakaan, sekreteraiat HMJ, dan kelas. Wawancara dilakukan terhadap mahasiswa HMJ, juga kepada pengelola perpustakaan, dosen, serta pejabat-pejabat kampus yang diperlukan. Untuk menjaring data yang lebih banyak, digunakan kuesioner yang ditujukan kepada para mahasiswa menggunakan aplikasi google form yang dibantu sebarkan oleh perwakilan mahasiswa HMJ masing-masing fakultas. Pada tahap akhir, untuk melakukan kroscek data dan penggalian data pelengkap digunakan focus group discussion dengan beberapa perwakilan mahasiswa HMJ. 
Data utama yang dikumpulkan dalam kajian adalah data terkait sembilan aspek praktik literasi yang sudah disebutkan di awal. Operasionaliasi aspek tersebut dituangkan dalam pertanyaan berikut.

1. Topik atau isu: topik dan isu apa yang dibaca/ditulis mahasiswa, mengapa?

2. Gaya dan konvensi, genre teks seperti apa yang dibaca/ditulis mahasiswa, mengapa?

3. Mode dan teknologi, apakah aktifitas membaca/menulis mahasiswa masih menggunakan mode konvensional atau teknologi?

4. Tujuan, tujuan apa yang digapai mahasiswa dalam membaca/ menulis?

5. Fleksibilitas dan kendala, kapan dan dimana mahasiswa membaca/menulis

6. Aksi dan proses, bagaimana proses membaca/menulis?

7. Audiens, dimana posisi mahasiswa saat membaca/menulis?

8. Peran dan identitas, saat sebagai apa mahasiswa membaca/ menulis?

9. Interaksi dan kolaborasi, bagaimana interaksi mahasiswa dalam membaca/menulis?

Kajian ini dapat digolongkan sebagai studi kasus, yaitu studi deskripsi mendalam pada satu kelompok atau peristiwa, yang dalam hal ini adalah studi pada praktik literasi di kampus UIN Sunan Ampel Surabaya. Langkah dasarnya adalah: pengumpulan data, analisis, dan menulis. Permasalahan yang ditemukan jawabannya dalam bentuk data informasi kemudian dikembangkan dalam suatu kerangka analisis untuk memecahkan masalah kemudian menuliskannya dengan menciptakan suasana di lapangan yang juga membagi pengalaman pengkaji di lapangan kepada pembaca (Bungin 2007).

Analisis data kajian ini memanfaatkan teori SWOT yang pada awalnya populer untuk analisis bisnis (David 2006; Rangkuti 2006; Jogiyanto 2005). Analisis SWOT dianggap bisa membantu mengkaji faktor internal dan eksternal yang ada di kampus UINSA Surabaya untuk melihat kondisi literasi dan menciptakan strategi 
mewujudkan kampus literat. Hubungan dan strategi faktor analisis SWOT dapat digambarkan dalam tabel 1 (Rangkuti 2006). Dalam teori lain, penggunaan istilah yang ada dalam kerangka SWOT (kekuatan, kelemahan, peluang, dan ancaman) dapat dipadankan dengan faktor pendukung dan penghambat atau selisih antara kondisi faktual dengan kondisi ideal (Van Kooij 2007).

Analisis kekuatan, kelemahan, tantangan, dan peluang pada praktik literasi di kampus UINSA Surabaya menjadi kajian lanjutan untuk merumuskan kondisi kampus literat. Keberhasilan mencapai kondisi yang diinginkan dipengaruhi oleh banyak faktor, baik faktorkekuatan yang mendorong berhasilnya kondisi itu, ataupun faktor kendala yang menghambat pencapaiannya. Kekuatan dan kendala adalah faktor internal yang berpengaruh dalam penciptaan suasana literat di kampus UINSA Surabaya. Selain faktor internal juga terdapat faktor eksternal berupa peluang dan tantangan yang dapat berpengaruh baik langsung maupun tidak langsung terhadap pencapaian tujuan terwujudnya iklim literat di UINSA Surabaya.

Tabel 1. Hubungan strategi faktor analisis SWOT

\begin{tabular}{lll}
\hline & Kekuatan (Strength) & Kelemahan (Weaknes) \\
\hline $\begin{array}{l}\text { Peluang } \\
\text { (Opportunity) }\end{array}$ & $\begin{array}{l}\text { Strategi SO Ciptakan strategi } \\
\text { yang menggunakan kekuatan } \\
\text { untuk memanfaatkan }\end{array}$ & $\begin{array}{l}\text { Strategi WO } \\
\text { Ciptakan strategi yang } \\
\text { meminimalkan kelemahan }\end{array}$ \\
\hline $\begin{array}{l}\text { Ancaman } \\
\text { (Threats) }\end{array}$ & $\begin{array}{l}\text { Strategi ST Ciptakan strategi } \\
\text { untuk memanfaatkan peluang }\end{array}$ \\
& $\begin{array}{l}\text { Strategi WT } \\
\text { untuk mengatasi ancaman }\end{array}$ & $\begin{array}{l}\text { Ciptakan strategi yang } \\
\text { meminimalkan kelemahan dan } \\
\text { menghindari anca man }\end{array}$ \\
\hline
\end{tabular}

Sumber: (Rangkuti 2006)

\section{Gambaran Umum UIN Sunan Ampel}

Universitas Islam Negeri Sunan Ampel Surabaya (disingkat UINSA) merupakan salah satu kampus Islam tertua di Indonesia yang meneguhkan diri sebagai pusat pengembangan dan penyebaran peradaban Islam Indonesia rahmatan lil'alamin. Pembumian Islam Indonesia di UINSA diarahkan kepada hadirnya manusia- 
manusia yang memiliki kemampuan membaca dan memahami kearifan dalam sejarah Islam serta mempunyai kapabilitas keilmuan kontemporer sesuai dengan bidang yang digeluti beserta keilmuan pendukungnya. UINSA Surabaya mengembangkan keilmuan berparadigma integrated twin towers sebagai pola pengintegrasian ilmu-ilmu keislaman dengan disiplin keilmuan lain. Paradigma keilmuan UINSA ini disimbolisasikan secara fisik pada gedung twin towers yang kini sedang dibangun, yang disupport oleh Islamic Development Bank (IDB) (Sambutan Rektor UINSA 5 Januari 2015, dalam http://www.uinsby.ac.id/id).

\section{Gambar 1}

Twin Tower UINSA

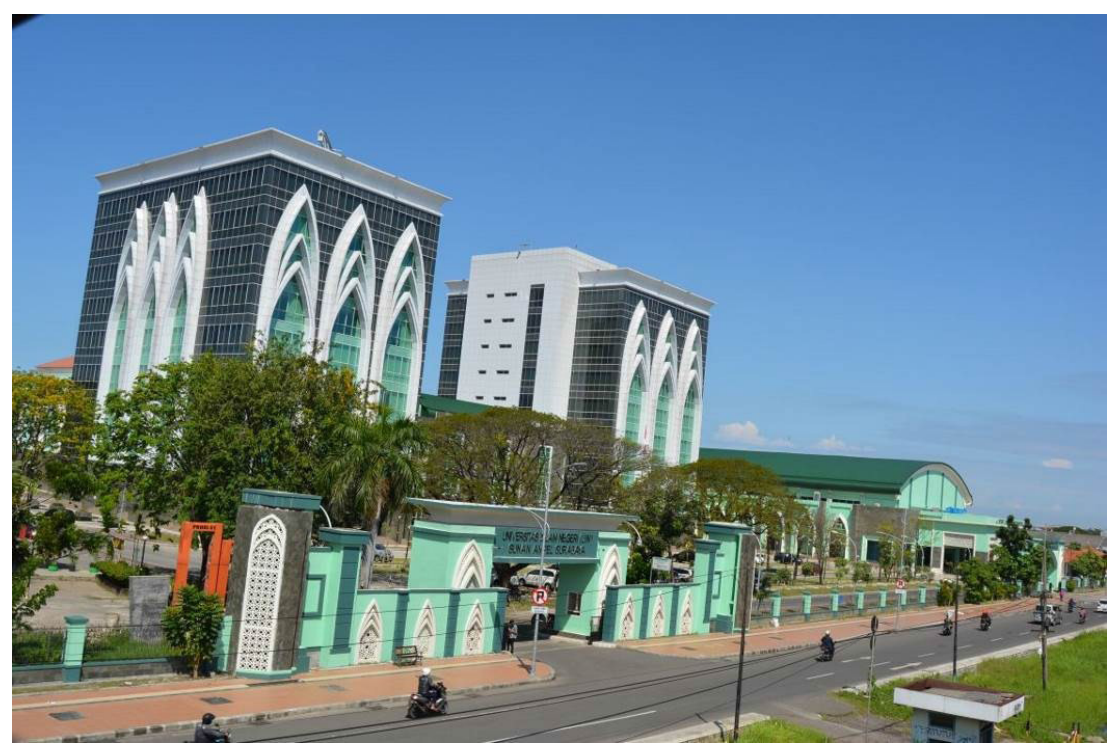

Sumber: http://jurnalposmedia.blogspot.com/2016/07/twin-tower-beri-warnabaru-uin-surabaya.html

Gambar 1 yang menunjukkan gedung kembar di UINSA ternyata tidaklah menjadi sebuah ikon gedung baru yang diunggulkan karena kemewahannya, melainkan lebih dimaknai sebagai sebuah simbol bahwasanya UINSA menggabungkan dan menjembatani dua klasifikasi keilmuan yang dibutuhkan mahasiswa dan masyarakat pada umumnya, yaitu keilmuan umum dan keilmuan agama. Gedung pertama dapat dimaknai sebagai keilmuan Islam yang menjadi ciri awal perguruan tinggi Islam (IAIN-UIN), se- 
dangkan gedung kedua dimaknai keilmuan umum. Dua gedung ini diintegrasikan, dihubungkan dengan adanya jembatan yang menjadikan dua gedung atau dua keilmuan ini selalu berhubungan dan memberi keseimbangan satu sama lain.

\section{Konteks Sosial Budaya UINSA, Paradigma dan Filosofi Pendidikan}

Setelah berubah menjadi universitas dengan lahirnya PP RI Nomor 65 Tahun 2013, UINSA mengusung paradigma keilmuan baru yang disebut dengan model menara kembar tersambung (integrated twin-towers). Model integrated twin-towers merupakan pandangan integrasi akademik bahwa ilmu-ilmu keislaman, sosial humaniora, serta sains dan teknologi yang berkembang sesuai dengan karakter dan obyek spesifik yang dimiliki, tetapi dapat saling menyapa, bertemu dan mengaitkan diri satu sama lain dalam suatu pertumbuhan yang terkoneksi. Model integrated twin-towers bergerak bukan dalam kerangka Islamisasi ilmu pengetahuan, melainkan Islamisasi nalar yang dibutuhkan untuk terciptanya tata keilmuan yang saling melengkapi antara ilmu-ilmu keislaman, sosialhumaniora, serta sains dan teknologi (UINSA 2015).

Akh. Muzakki, Ketua Tim Konversi UINSA memberikan keterangan bahwa desain akademik yang didasarkan pada paradigma integrated twin towers ini memiliki peranan penting untuk lahirnya integrasi keilmuan yang baik dengan memberi manfaat akademik resiprokal yang kuat kepada disiplin keilmuan yang berbeda-beda di dalam struktur kelembagaan UINSA. Peranan pentingnya sebagaimana berikut: "Harapannya, melalui pengembangan kelembagaan dalam wadah UIN, IAIN Sunan Ampel Surabaya dapat memberi kontribusi perkembangan ilmu melalui menara kembar tersambung yang dibangun, dengan memberikan perhatian yang sama terhadap dua sisi ilmu (agama dan umum) sehingga dapat menjadi penerang bagi satu sama lain." (UINSA 2015).

Output pendidikan yang ingin diraih dari integrasi keilmuan berparadigma integrated twin towers di atas adalah terciptanya lulusan yang ulul albab. Alquran sebanyak 16 kali menyebut konsep ulul albab untuk menjelaskan pentingnya sumber daya manusia dengan kualifikasi personal dan sosial, akademik dan non-akademik, seperti yang salah satunya ingin diciptakan oleh UINSA. 
Melalui integrasi keilmuan berparadigma integrated twin towers, UINSA memaknai dan menerjemahkan secara lebih konkret konsep ulul albab ke dalam standar kompetensi lulusan yang memiliki kekayaan intelektual, kematangan spiritual, dan kearifan perilaku. Kekayaan intelektual diharapkan mampu mengantarkan individu lulusan yang memiliki kepribadian smart (cerdas). Kematangan spiritual diidealisasikan agar tertanam kuat dalam diri individu lulusan kepribadian honourable (bermartabat). Kearifan perilaku dimaksudkan agar individu lulusan diperkaya dengan kepribadian pious (berbudi Luhur) (UINSA 2015).

\section{Gambar 2}

Skema Pengembangan Keilmuan UINSA

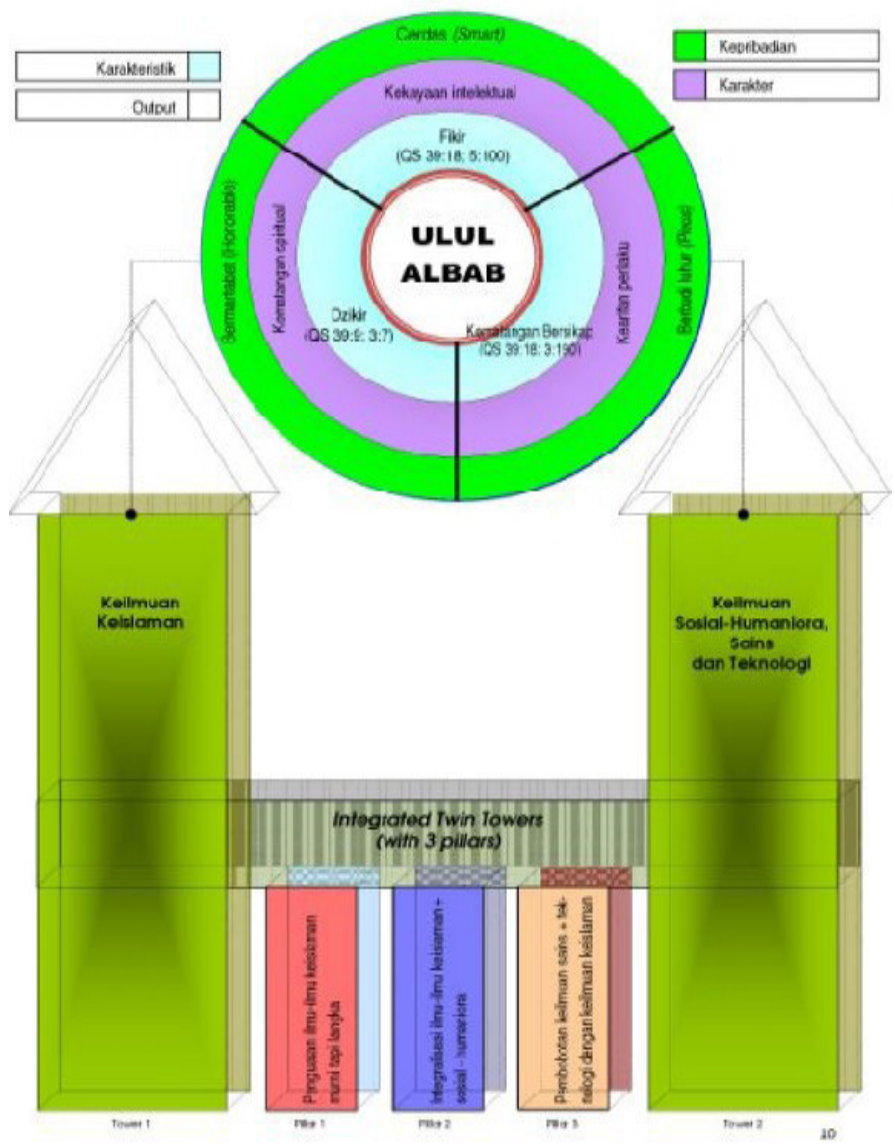

Sumber: Buku Desain Akademik UIN Sunan Ampel Surabaya (2013:47) dalam (UINSA 2015) 
Gambar 2 merupakan penegasan gambar sebelumnya, bahwasanya simbol dua gedung kembar yang terintegrasi juga menjadi paradigma berpikir pihak kampus. Tujuan UINSA adalah mencetak generasi yang ulul albab, generasi yang terdidik, tetapi terdidik yang seimbang antara kemampuan agama dan umum.

Selain memiliki paradigma integrated twin tower, UINSA juga telah menyusun filosofi penyelenggaraan pendidikan. Filosofi penyelenggaraan pendidikan UINSA adalah menemukan, mengembangkan, melakukan inovasi dan menyebarluaskan ilmu pengetahuan di bidang ilmu-ilmu keislaman, sosial-humaniora serta sains dan teknologi sehingga menghasilkan sumber daya manusia yang mandiri, unggul, kompetitif dan inovatif. Filosofi penyelenggaraan pendidikan tersebut diwujudkan melalui tiga pilar program akademik, terdiri dari: 1) penguatan ilmu-ilmu keislaman murni, tetapi langka; 2) integrasi keilmuan keislaman pengembangan dengan keilmuan sosial-humaniora, dan 3) pembobotan keilmuan sains dan teknologi dengan keilmuan keislaman (pedoman akademik UINSA).

\section{Kondisi Akademis UINSA}

Kurikulum yang digunakan oleh UINSA adalah kurikulum Kerangka Kualifikasi Nasional Indonesia (KKNI) yang merujuk pada Peraturan Presiden RI Nomor 8 Tahun 2012 tentang KKNI, juga Permendikbud RI Nomor 49 Tahun 2014 tentang Standar Nasional Pendidikan Tinggi (SNPT). Untuk pelaksanaanya, setiap program studi menyusun kurikulumnya sesuai dengan kebutuhan masing-masing.

Sebagai contoh, misalnya prodi Sistem Informasi, yang dalam pengantar panduan akademiknya menyatakan (Prodi Sistem Informasi, 2016: 2): 
Penyusunan kurikulum ini berdasar pada visi dan misi UIN Sunan Ampel Surabaya, tuntutan pasar kerja, dan perkembangan globalisasi. Dalam pelaksanaan penyusunan kurikulum ini dibantu dan didukung oleh sejumlah pihak yang terdiri dari komponen pengelola Program Studi, Pakar kurikulum, Pakar pendidikan Vokasi, dan Stakeholders, serta diawasi oleh Lembaga Penjaminan Mutu (LPM) UIN Sunan Ampel Surabaya.

Kerangka Kualifikasi Nasional Indonesia (KKNI) adalah kerangka penjenjangan kualifikasi dan kompetensi tenaga kerja Indonesia yang menyandingkan, menyetarakan, dan mengintegrasikan sektor pendidikann dengan sektor pelatihan dan pengalaman kerja dalam suatu skema pengakuan kemampuan kerja yang disesuaikan dengan struktur di berbagai sektor pekerjaan.

KKNI merupakan perwujudan mutu dan jati diri Bangsa Indonesia terkait dengan sistem pendidikan nasional, sistem pelatihan kerja nasional serta sistem penilaian kesetaraan capaian pembelajaran (learning outcomes) nasional, yang dimiliki Indonesia untuk menghasilkan sumberdaya manusia yang bermutu dan produktif.

KKNI merupakan sistem yang berdiri sendiri dan merupakan jembatan antara sektor pendidikan dan pelatihan untuk membentuk SDM nasional berkualitas dan bersertifikat melalui skema pendidikan formal, nonformal, informal, pelatihan kerja atau pengalaman kerja. KKNI terdiri dari 9 (sembilan) jenjang kualifikasi, dimulai dari kualifikasi 1 sebagai kualifikasi terendah hingga kualifikasi tertinggi (level 9). Kesetaraan capaian pembelajaran antara outcome pendidikan berbasis keilmuan, pendidikan berbasis keahlian, program profesi dan pengembaran karir di tempat kerja KKNI terdapat pada Gambar 3 berikut ini. 


\section{Gambar 3}

Kesetaraan 3 jenis pendidikan di KKNI

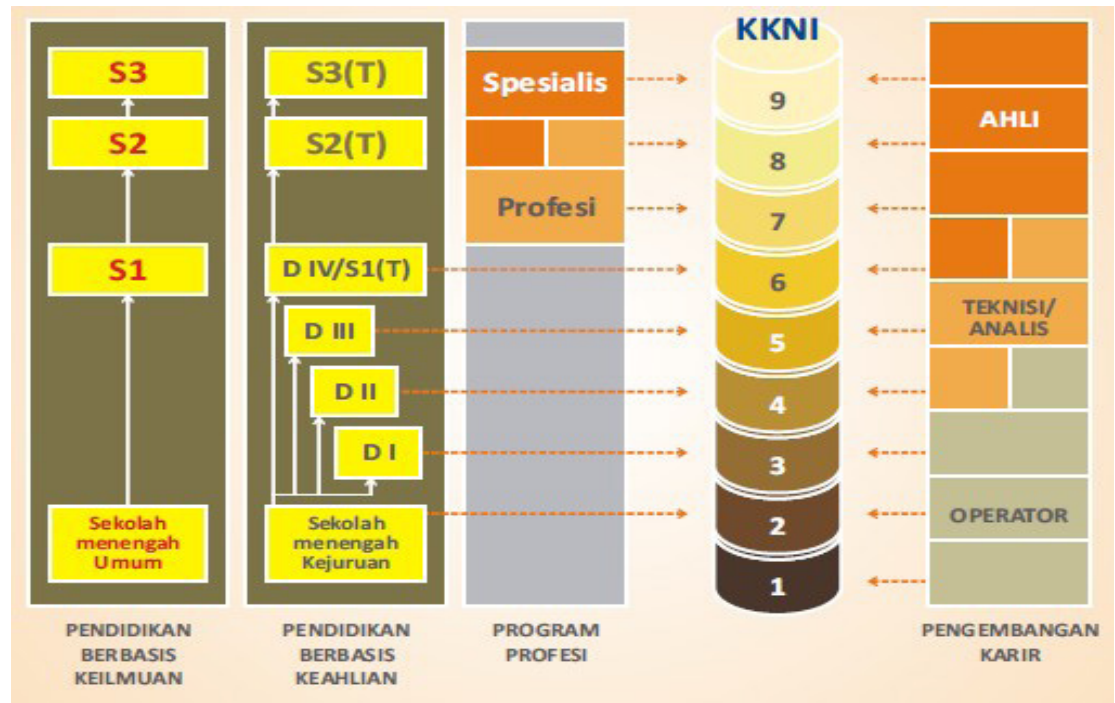

Sumber: (Prodi-Sistem-Informasi-UINSA 2016)

Adapun tujuan pengembangan kurikulum KKNI disesuaikan dengan dasar Peraturan Pemerintah RI nomor 19 tahun 2005 tentang Standar Nasional Pendidikan. Peraturan tersebut mengamanatkan bahwa kurikulum tingkat satuan pendidikan untuk setiap program studi di perguruan tinggi dikembangkan dan ditetapkan oleh masing-masing perguruan tinggi dengan mengacu Standar Nasional Pendidikan. Artinya setiap perguruan tinggi diberi kebebasan untuk mengembangkan kurikulum sendiri sesuai dengan visi misi, potensi daerah, dan potensi mahasiswa. Oleh karena itu pengembangan kurikulum KKNI di UINSA ditujukan untuk:

1. Meningkatkan mutu dan akseptabilitas lulusan Program Studi ke pasar kerja nasional dan internasional berdasarkan kearifan lokal.

2. Membangun proses pengakuan yang akuntabel dan transparan terhadap capaian pembelajaran program studi system informasi melalui pendidikan, penelitian, dan pengabdian masyarakat. 
3. Menjadi acuan operasional dalam implementasi kurikulum bagi seluruh civitas akademika di masing-masing Program Studi.

4. Menjadi acuan pengendalian, pengawasan dan penjaminan mutu dalam implementasi pelaksanaan kurikulum berbasis kompetensi yang merujuk pada KKNI (Prodi Sistem Informasi, 2016: 8)

Terkait kurikulum KKNI, M. Thohir, selaku Kabag Penjamin Mutu, menyatakan bahwa UINSA masih dalam proses pengumpulan kurikulum tiap Prodi dan Fakultas sejak 2016. Tingkat kesiapan masing-masing Prodi dan Fakultas berbeda, sebagai contoh Fakultas Tarbiyah sangat cukup keluarannya. Dalam kurikulum, literasi adalah program yang masuk dalam mata kuliah, tetapi di beberapa kasus juga tergantung masing-masing dosen (wawancara M Thohir, 22 Mei 2018).

UINSA telah bertransformasi dari institusi Islam ke universitas. Kurikulum KKNI yang dipilih oleh pada akhirnya memaksa UINSA untuk bisa menyesuaikan diri dalam mengelola dan memproduksi lulusan mahasiswanya agar tidak hanya memiliki kemampuan keilmuan (konsep) semata, tetapi jugaberpengalaman dalam mengaplikasikan keilmuannya di lapangan. Terkait hal ini pulalah, kegiatan kuliah kerja nyata yang diaplikasikan dalam berbagai bentuk menjadi kegiatan yang penting dipraktikkan oleh mahasiswa, dan salah satu keluaran kemampuan yang diajarkan adalah kemampuan literasi.

\section{Kondisi Literasi UIN Sunan Ampel}

Latar dan kondisi literasi UINSA secara umum dapat dilihat dari perpustakaan, LP2M, dan Literasi umum. Perpustakaan di UINSA terbagi atas dua kategori, yaitu Perpustakaan Pusat (Universitas) dan Perpustakaan Fakultas. Kajian hanya mencukupkan kepada pantauan terhadap Perpustakaan Pusat (Universitas) yang dianggap sudah cukup mewakili. Demikian pula, dalam program LP2M, terdapat banyak hal, tetapi dalam kajian ini dibatasi pada beberapa saja, utamanya program KKN. Literasi umum di sini terdiri dari pers mahasiswa dan juga literasi lainnya. 


\section{Perpustakaan UINSA}

Perpustakaan pusat UINSA sudah memiliki infrastruktur yang memadai jika dilihat dari bangunan gedung, fondasi visi misi perpustakaan yang jelas, koleksi yang dapat diakses secara langsung (berbentuk cetak) maupun online (yang terdiri dari Ebook, jurnal, dan repository) (http://www.library.uinsby.ac.id.; Iswanto et al. 2019).

Koleksi perpustakaan UINSA yang berhasil dilihat sebagai data kajian ini adalah statistik koleksi 2017 dan 2016 yang dapat dilihat dalamm tabel 2. Hal yang menarik dilihat bahwa judul-judul yang populer dipinjam lebih pada judul bacaan perkuliahan, sehingga tidak dapat mewakili minat bacaan yang dipilih mahasiswa.

Tabel 2. Statistik koleksi perpustakaan UINSA

\begin{tabular}{lll}
\hline Tahun & 2017 & 2016 \\
\hline Total Judul & 75.318 & 72.999 \\
\hline Total Judul dengan eksemplar & 60.762 & 58.259 \\
\hline Total Eksemplar/Kopi & 119.450 & 112.790 \\
\hline Total Eksemplar dipinjam & 2.168 & 1.842 \\
\hline Total Eksemplar dalam koleksi & 117.282 & 110.948 \\
\hline Total Judul Menurut Media: & & \\
\hline a) Buku & 34.588 & 33.866 \\
\hline b) Skripsi & 24.638 & 23.610 \\
\hline c) Artikel & 9.503 & 9.047 \\
\hline d) Koran & 4.298 & 4.310 \\
\hline e) Tesis & 1.220 & 1.102 \\
\hline f) Jurnal & 277 & 276 \\
\hline g) American Corner & 254 & 254 \\
\hline h) Disertasi & 132 & 109 \\
\hline i) Print & 3 & 2 \\
\hline
\end{tabular}




\section{Total Eksemplar Menurut Koleski:}

\begin{tabular}{|c|c|c|}
\hline a) Koleski Umum & 75.501 & 71.005 \\
\hline b) Koleksi Khusus & 26.528 & 25.344 \\
\hline c) Koleksi Tandon & 12.655 & 11.897 \\
\hline d) Koleksi Reference & 5.480 & 5.298 \\
\hline e) Koleksi Islam Indonesia & 40 & \\
\hline \multirow[t]{9}{*}{10 Judul Terpopuler } & \multicolumn{2}{|c|}{$\begin{array}{l}\text { Metode Penelitian Kualitatif/Lexy J. } \\
\text { Moleong }\end{array}$} \\
\hline & \multicolumn{2}{|c|}{$\begin{array}{l}\text { Metode Penelitian Kuantitatif: komunikasi, } \\
\text { ekonomi, dan kebijakan publik dst/M. } \\
\text { Burhan Bungin }\end{array}$} \\
\hline & \multicolumn{2}{|c|}{$\begin{array}{l}\text { Kepribadian jilid 1: teori klasik dan riset } \\
\text { modern/Howard S. Friedman }\end{array}$} \\
\hline & \multicolumn{2}{|c|}{$\begin{array}{l}\text { Penelitian Kualitatif: komuniasi, ekonomi, } \\
\text { dst/M. Burhan Bungin }\end{array}$} \\
\hline & \multicolumn{2}{|c|}{$\begin{array}{l}\text { Teologi Islam: aliran-aliran sejarah analisa } \\
\text { perbandingan/Harun Nasution }\end{array}$} \\
\hline & \multicolumn{2}{|c|}{$\begin{array}{l}\text { Psikologi Belajar/Abu Ahmadi, Widodo } \\
\text { Supriyono }\end{array}$} \\
\hline & \multicolumn{2}{|c|}{$\begin{array}{l}\text { Sejarah Peradaban Islam II: dirasah } \\
\text { Islamiyah/Badri Yatim }\end{array}$} \\
\hline & \multicolumn{2}{|c|}{$\begin{array}{l}\text { Metode Penelitian Kualitatif: paradigma } \\
\text { baru ilmu komunikasi dst/Deddy } \\
\text { Mulyana }\end{array}$} \\
\hline & \multicolumn{2}{|c|}{$\begin{array}{l}\text { Hukum perkawinan Islam di Indonesia: } \\
\text { antara fiqh munakahat dst/Amir } \\
\text { Syarifuddin }\end{array}$} \\
\hline
\end{tabular}

Sumber: Observasi penulis; (Iswanto et al. 2019)

Data peminjaman buku perpustakaan UINSA tiap bulan selama tahun 2017 tercatat yang tertinggi ada pada bulan Maret hingga mencapai 25 ribu, sedangkan peminjaman terendah yaitu pada bulan Januari dan dua bulan libur kenaikan tingkat yaitu JuliAgustus.

Adapun kunjungan perpustakaan, berdasarkan rekap peminjaman pustaka, kunjungan tertinggi terjadi pada bulan September dan Maret yaitu bulan-bulan awal memasuki semester baru. Kunjungan terendah terjadi pada masa libur semester yaitu bulan Januari, Juli, dan Agustus. Rekap statistik pengunjung dapat dilihat secara lengkap dalam tabel 3. 
Umi selaku ketua perpustakaan menyatakan bahwa kunjungan anggota yang utama adalah dari para mahasiswa strata 1 , kemudian selisih kunjungan mahasiswa selama dua tahun tidak terlalu mencolok meskipun ada peningkatan (wawancara dengan Umi 17 Mei 2018).

Tabel 3. Statistik pengunjung tahun 2017

\begin{tabular}{lllllllll}
\hline $\begin{array}{l}\text { Tipe } \\
\text { Keanggotaan }\end{array}$ & Mahasiswa Dosen Karyawan DLB & $\begin{array}{c}\text { Tamu } \\
\text { instansi }\end{array}$ & $\begin{array}{c}\text { Pasca } \\
\text { Sarjana }\end{array}$ & $\begin{array}{l}\text { Pengunjung } \\
\text { Bnggota }\end{array}$ & $\begin{array}{c}\text { Total } \\
\text { kunjungan/ } \\
\text { bulan }\end{array}$ \\
\hline Jan & 1897 & 9 & 0 & 0 & 1 & 36 & 0 & 1943 \\
\hline Feb & 8882 & 31 & 1 & 0 & 0 & 54 & 0 & 8968 \\
\hline Mar & 23327 & 15 & 0 & 0 & 0 & 69 & 0 & 23411 \\
\hline Apr & 14330 & 7 & 0 & 0 & 0 & 64 & 0 & 14401 \\
\hline Mei & 13481 & 20 & 0 & 0 & 0 & 84 & 0 & 13585 \\
\hline Jun & 4625 & 3 & 0 & 0 & 0 & 25 & 0 & 4653 \\
\hline Jul & 1524 & 2 & 0 & 0 & 0 & 13 & 0 & 1539 \\
\hline Agu & 2371 & 12 & 2 & 3 & 0 & 26 & 0 & 2414 \\
\hline Sep & 25283 & 17 & 1 & 0 & 0 & 31 & 0 & 25332 \\
\hline Okt & 21777 & 17 & 0 & 4 & 5 & 142 & 0 & 21945 \\
\hline Nop & 19293 & 13 & 0 & 2 & 11 & 104 & 0 & 19423 \\
\hline Des & 14869 & 9 & 0 & 3 & 8 & 90 & 0 & 14979 \\
\hline
\end{tabular}

Sumber: Diolah dari data LPJ perpustakaan UINSA 2017

Perpustakaan UINSA telah membuat aturan pelayanan dan larangan. Penjelasan layanan perpustakaan dapat diakses dalam halaman web perpustakaan UINSA pada bagian service. Pelayanan perpustakaan UINSA terdiri dari berbagai hal yaitu: layanan sirkulasi (peminjaman), layanan referensi (bantuan dan bimbingan mencari referensi), layanan koleksi khusus (koleksi karya institusi yang hanya bisa dibaca di tempat), layanan audio visual, layanan nonton bareng (pemutaran film baru seminggu sekali), layanan photo copy, layanan bimbingan pemakai (orientasi perpustakaan kepada mahasiswa baru), layanan ruang baca, layanan permohonan judul buku, layanan pemesanan buku, layanan kartu sakti (kerjasama perpustakaan UINSA dengan perpustakaan lain/luar), 
dan book reserve (peminjaman buku yang intensitas peminjamannya tinggi). Selain layanan, perpustakaan UINSA telah menyusun peraturan yang terdiri dari larangan, keanggotaan (internal dan eksternal civitas UINSA), hak keanggotaan dari lembaga lain, kunjungan (aturan absensi, kartu anggota, dan kode etik), sanksi (terkait keterlambatan, kerusakan, perpanjangan, dan seterusnya), dan bebas pinjaman (sebagai syarat mahasiswa pindah, cuti, dan wisuda) (wawancara dengan Umi 17 Mei 2018).

Perpustakaan UINSA sebagaimana yang diharapkan sebagai garda depan literasi juga telah menyusun beberapa program pendukung literasi tiap tahun selain pelayanan keseharian terhadap warga UINSA. Program-program pendukung literasi di Perpustakaan UINSA di antaranya: 1) pelatihan bagi mahasiswa baru, 2) pelatihan penyusunan tugas akhir, 3) pelatihan e-journal, 4) perlombaan perpustakaan, 5)workshop indeksisasi, 6) pelatihan uploud mandiri bagi mahasiswa tigkat akhir, dan 7) bedah buku (Wawancara dengan Umi, 22 Mei 2018).

Program perpustakaan yang diperuntukkan untuk umum misalnya adalah bedah buku dan diskusi. Di antaranya pada tahun 2016 dilaporkan kegiatan bedah buku "Islam Nusantara" dan "Islam Berkemajuan". Program ini dilaksanakan dalam rangka mendukung program Surabaya Berliterasi, yaitu dengan menumbuhkan budaya baca dan budaya akademik khususnya di lingkungan UIN Sunan Ampel dan sebagai strategi pendekatan perpustakaan kepada pemustaka (Perpustakaan UINSA, 2016: 1-4). Acara bedah buku dilaksanakan pada 7 September 2016 dengan agenda acara sebagai berikut.

Tabel 4. Jadwal Buku Perpustakaan UINSA

\begin{tabular}{|c|c|c|}
\hline Waktu & Nara Sumber & $\begin{array}{l}\text { Moderator/ } \\
\text { pelaksana }\end{array}$ \\
\hline 07.30 s.d 08.30 WIB & $\begin{array}{l}\text { Pendaftaran } \\
\text { Peserta }\end{array}$ & Panitia \\
\hline $08.3009 .00 \mathrm{WIB}$ & $\begin{array}{l}\text { Pembukaan dan } \\
\text { Pembagian Hadiah } \\
\text { Lomba Desain Id } \\
\text { Card }\end{array}$ & $\begin{array}{l}\text { Kepala } \\
\text { Perpustakaan }\end{array}$ \\
\hline
\end{tabular}




\begin{tabular}{|c|c|c|c|}
\hline 09.00 s.d 11.00 WIB & $\begin{array}{l}\text { Pembahas Buku } \\
\text { Islam Nusantara }\end{array}$ & $\begin{array}{l}\text { Munawir Aziz, } \\
\text { MA (edtor dan } \\
\text { contributor buku) }\end{array}$ & \\
\hline 11.00 s.d 13.00 WIB & $\begin{array}{l}\text { Pembahas } \\
\text { Buku Islam } \\
\text { Berkemajuan }\end{array}$ & $\begin{array}{l}\text { Dr. Pradana Boy, } \\
\text { MA (contributor } \\
\text { buku) }\end{array}$ & \\
\hline 13.00 s.d 14.00 WIB & Pembanding & $\begin{array}{l}\text { Dr. Masdar Hilmy, } \\
\text { MA. (Guru Besar } \\
\text { UIN Sunan Ampel } \\
\text { Surabaya) }\end{array}$ & \\
\hline 14.00 s.d 15.00 WIB & Sesi Tanya Jawab & & $\begin{array}{l}\text { Dr. Nabila } \\
\text { Naily, M.Si. }\end{array}$ \\
\hline
\end{tabular}

Sumber: Perpustakaan UINSA, 2016: 5-6

Selain menambah wawasan dan ilmu pengetahuan kepada peserta, pencapaian kegiatan bedah buku ini di antaranya adalah besarnya minat mahasiswa yang mengikuti kegiatan, terjalinnya kerjasama perpustakaan UINSA dengan penerbit buku (Mizan), dan dengan penerbit buku Mizan. Beberapa penerbit lain juga berkesempatan untuk mengelar produk pada acara ini, dan terdapat kontribusi buku dari penerbit (Perpustakaan UINSA, 2016: 9).

\section{Gambar 4}

Dokumentasi Bedah Buku
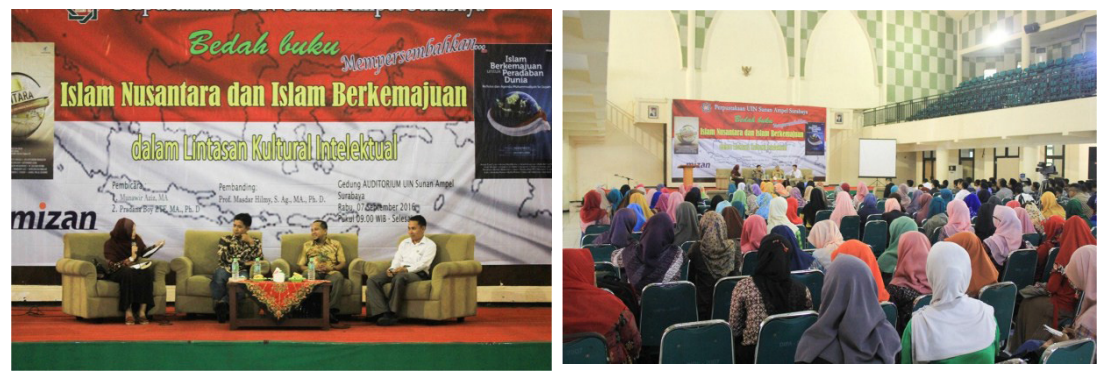

Sumber: Dokumentasi Perpustakaan UINSA LP2M UIN Sunan Ampel

Di antara program kerja Lembaga Pengabdian dan Pengembangan Masyarakat (LP2) UINSA adalah program kuliah kerja nyata (KKN) yang setidaknya dalam konteks kajian ini dibedakan menjadi dua macam: KKN umum dan KKN Literasi. 
Dilihat dari lokasi, KKN UINSA dibedakan menjadi yang dilaksanakan di dalam kota (Surabaya), luar kota/kabupaten, luar propinsi, bahkan luar negeri dengan berbagai kriteria pemilihan. Lokasi di luar kota yang paling sering dikunjungi adalah Kab. Bojonegoro, Kab. Madiun, dan Kab. Magetan. Lokasi luar propinsi yang sudah dilakukan misalnya ke NTT, NTB, dan Papua. Sedangkan lokasi di luar negeri yang sudah dilakukan adalah ke Malaysia, Thailand, dan Belanda. Dilihat dari waktu ada program yang setahun sekali, ada yang dua kali. Dilihat dari sasaran, ada yang ke sekolah, masyarakat, dan instansi. Sedangkan dilihat dari program, ada program reguler dan program khusus. Program yang sedang populer di UINSA adalah KKN Literasi.

Untuk mempermudah kriteria KKN UINSA, dapat dilihat dalam tabel contoh berikut.

Tabel 5. Kriteria KKN UINSA

\begin{tabular}{|c|c|c|c|c|}
\hline Program KKN & Tempat & Waktu & Sasaran & Keterangan \\
\hline KKN Reguler & Jawa Timur & $\begin{array}{l}2 \text { bulan, } \\
2 x / \text { tahun }\end{array}$ & Masyarakat & $\begin{array}{l}\text { Program KKN } \\
\text { pengabdian } \\
\text { kepada } \\
\text { masyarakat } \\
\text { dengan berbagai } \\
\text { tema. }\end{array}$ \\
\hline KKN Literasi & Kota Surabaya & $\begin{array}{l}2 \text { bulan, } \\
2 x / \text { tahun }\end{array}$ & $\begin{array}{l}\text { Madrasah dan } \\
\text { Perpustakaan } \\
\text { Masyarakat }\end{array}$ & $\begin{array}{l}\text { Meningkatkan } \\
\text { literasi siswa } \\
\text { madrasah, } \\
\text { meningkatkan } \\
\text { manajemen } \\
\text { perpustakaan. }\end{array}$ \\
\hline \multirow[t]{2}{*}{$\begin{array}{l}\text { KKN } \\
\text { Kerjasama }\end{array}$} & $\begin{array}{l}\text { Luar Propinsi: } \\
\text { NTT }\end{array}$ & $\begin{array}{l}2 \text { bulan, } \\
\text { Temporal }\end{array}$ & Masyarakat & $\begin{array}{l}\text { Bekerjasama } \\
\text { dengan Universitas } \\
\text { Muhammadiya h } \\
\text { (UNMUH) } \\
\text { dan Sekolah Tinggi } \\
\text { Ilmu Tarbiyah } \\
\text { (STIT) }\end{array}$ \\
\hline & $\begin{array}{l}\text { Daerah } \\
\text { Tertinggal } \\
\text { (NTT, NTV, } \\
\text { Sorong Papua). }\end{array}$ & Temporal & Masyarakat & $\begin{array}{l}\text { Melakukan } \\
\text { pembimbingan } \\
\text { kepada } \\
\text { masyarakat }\end{array}$ \\
\hline
\end{tabular}




\begin{tabular}{|c|c|c|c|}
\hline $\begin{array}{l}\text { Luar Negeri } \\
\text { (Malaysia, } \\
\text { Thailand, } \\
\text { Belanda) }\end{array}$ & $\begin{array}{l}5-6 \text { bulan, } \\
1 x \text { setahun }\end{array}$ & Masyarakat & $\begin{array}{l}\text { Malasysia: } \\
\text { berdakwah } \\
\text { di daerah } \\
\text { perbatasan. } \\
\text { Thailand: } \\
\text { mengajar dan } \\
\text { berdakwah di } \\
\text { pesantren. } \\
\text { Belanda: } \\
\text { mengenalkan } \\
\text { Islam Indonesia } \\
\text { kepada keturunan } \\
\text { Indonesia. }\end{array}$ \\
\hline $\begin{array}{l}\text { Dinas/Instansi } \\
\text { Pemerintah } \\
\text { Kota Surabaya } \\
\text { (Koperasi, PU) }\end{array}$ & $\begin{array}{l}2 \text { bulan, } \\
\text { Temporal }\end{array}$ & $\begin{array}{l}\text { Pemerintah dan } \\
\text { Masyarakat }\end{array}$ & $\begin{array}{l}\text { Koperasi: } \\
\text { pendampingan } \\
\text { dan manajerial } \\
\text { pedagang } \\
\text { kelontong } \\
\text { PU: KKN } \\
\text { interdisipliner } \\
\text { untuk membantu } \\
\text { Dinas PU } \\
\text { mewujudkan kota } \\
\text { tanpa kumuh. }\end{array}$ \\
\hline
\end{tabular}

Sumber: Data yang diolah peneliti

Tabel 5 mempertegas bahwa posisi KKN Literasi merupakan bagian dari pilihan program KKN yang dijalankan oleh UINSA. KKN Literasi ini pada saat penelitian juga masih program baru yang belum lama dijalankan sehingga sasaran yang dituju juga masih berada di lokus Kota Surabaya, dengan objek sasaran adalah Madrasah dan perpustakaan Masyarakat. Setelah beberapa tahun, program KKN Literasi ini akan terus berkembang memperluas sasaran, objek, serta tema yang dituju.

Ketua LP2M menyatakan bahwa program dan model KKN di UINSA terus berkembang dari waktu ke waktu. Sebagai contoh, KKN Literasi baru dua atau tiga tahun digagas oleh Fakultas Tarbiyah. KKN Kerjasama biasanya diawali dengan adanya MoU kerjasama sebelumnya seperti yang dilakukan antar kampus, atau dengan adanya hubungan diplomasi dengan negara lain, atau bisa berdasar permintaan langsung dari pemerintah daerah (Wawancara, Dr. Fatoni H, 16 Mei 2018). 
"Ada pula KKN Koperasi. Dimintai langsung oleh Bu Risma, sebagai langkah memerangi peran supermarket dan kekuasaan Cina. KKN bertugas memberikan pendampingan kepada penjual kelontong, terutama dibidang manajemennya," (Fatoni H, 16 Mei 2018).

KKN di Luar Negeri juga dapat dianggap program baru yang terus berkembang. Fasilitas dan cara yang ditmpuh oleh mahasiswa juga berbeda tiap tempat. Mahasiswa yang melaksanakan KKN di Malaysia dan Thailand mendapatkan biaya transportasi dari lembaga dakwah di sana, smentara UIN membantu pengurusan paspor. Di Thailand, mahasiswa tinggal di rumah-rumah penduduk, yang sebagian non muslim. Mahasiswa yang melaksanakan KKN di Belanda mendapat uang makan, biaya hidup, bahkan gaji oleh badan alumni Internasional.

Agenda kerjasama terus dijalankan. Untuk agenda yang akan datang, akan dilaksanakan penelitian kolaboratif tiga judul pertahun dengan negara Turki, Belanda, dan negara Asia. KKN akan dilakukan pula ke negara Jerman. Mahasiswa UINSA yang dikirim ke negara Eropa umumnya untuk berdakwah dan mengenalkan kembali Islam Nusantara kepada generasi keturunan Indonesia yang bermukim di negara tersebut, yang umumnya sudah generasi ketiga atau lebih yang sudah semakin asing dengan Indonesia, khususnya Islamnya.

Awal mula dicetuskannya KKN literasi di UINSA memiliki keterkaitan dengan program yang ditawarkan oleh USAID. USAID menawarkan kerjasama pengembangan mahasiswa $(\mathrm{KKN})$ pada tahun 2013. Pada saat itu, banyak perwakilan kampus melalui LPPM yang diundang mempresentasikan program kerja masing-masing. Kemudian UINSA terpilih oleh USAID untuk melaksanakan program kerjasama yang utamanya ada tiga hal: teaching learning, MBS (manajemen berbasis sekolah), dan literasi. Kurikulum 2013 sangat mendukung program literasi, dan fakta tingkat literasi bangsa Indonesia masih rendah mendorong UINSA menggagas program literasi menjadi setidaknya dua produk, yaitu Aplikasi literasi dan KKN literasi (wawancara Evi F R 17 Mei 2018).

Program KKN literasi adalah melakukan pendampingan literasi yang memadukan Tri Dharma, yaitu pendidikan dan pengajaran, penelitian, serta pengabdian kepada masyarakat dalam satu kegiatan. Program KKN literasi ini pada awalnya ditujukan untuk 
mengembangkan budaya baca di madrasah dan mengoptimalkan peran perpustakaan sebagai salah satu sarana penunjang pembelajaran. Untuk mengantisipasi agar kemandirian madrasah dalam berliterasi berlanjut, maka digunakan pendekatan ABCD (Asset Basic Community Develepment) (Rusydiyah 2017).

KKN literasi adalah KKN kemitraan, dalam arti bekerjasama dengan Pemerintah Daerah, dalam hal ini Pemkot Surabaya. Surabaya termasuk salah satu kota yang mulai mengawali pengembangan budaya literasi di antaranya dengan sudut baca, bedah buku, diskusi buku, grebek TBM (taman baca masyarakat), dan lain-lainnya. Dengan adanya program ini, berdasar data statistik minat baca masyarakat mengalami peningkatan. Pemerintah kota Surabaya yuga melakukan pendampingan di lembaga formal, yaiu pendampingan penataan perpustakaan dan pelaksanaan Kurikulum Wajib Baca. Adapun di Madrasah dan Pondok Pesantren, yang berada di wilayah Kementerian Agama, program literasi tersebut belum maksimal. Di titik posisi terakhir inilah, KKN Literasi UINSA berupaya menyasar. Dengan demikian, KKN literasi UINSA dibatasi pada tujuan mendorong terciptanya minat baca dan meningkatkan sumber daya manusia peserti didik di madrasah dan pondok pesantren melalui budaya literasi (Rusydiyah, 2017: 6, 9).

Sebagaimana disinggung di awal, metode KKN Literasi ini adalah $\mathrm{ABCD}$, dalam arti bahwa untuk merumuskan agenda perubahan terkait budaya literasi madrasah dan pondok pesantren, maka dilibatkanlah peran warga masyarakat. Paradigma pendekatan $\mathrm{ABCD}$ adalah memahami aset, potensi, kekuatan dari masyarakat, dan pendayagunaannya secara maksimal. Adapun prinsip pendekatan $\mathrm{ABCD}$ adalah: 1) setengah terisi lebih berarti; 2) semua punya potensi; 3) partisipasi; 4) kemitraan; 5) penyimpangan positif; 6) berasal dari masyarakat (local endegenous); dan 7) mengarah pada sumber energi (Rusydiyah, 2017: 17-25).

Di lapangan, para mahasiswa yang melakukan KKN literasi menerapkan dua program utama: 1) pemakaian aplikasi literasi, 2) revitalisasi atau managering perpustakaan dan KWB (kurikulum wajib baca) dengan metode $A B C D$. Metode ABCD telah diuraikan sebelumnya. Evi FR selaku kepala Lab. Tarbiyah memberikan informasi terkait aplikasi ini sebagai berikut (wawancara 17 Mei 2018). 
"Aplikasi literasi adalah produk yang dihasilkan dari Fakultas Saintek berupa aplikasi reading ayo membaca (Assesor). Aplikasi ini memandu membaca para siswa (anak usia dini dan dasar). Aplikasi ini masih offline dan akan terus dikembangakan. Di dalam versi terakhir terdapat levelling buku teks, dengan menggunakan kerangka teori Fontes Empire. Di dalam aplikasi terdapat 11 paket, tiap paket ada 7 level buku, sehingga totalnya ada 77 judul buku bacaan." (Wawancara dengan Evi FR pada 17 Mei 2018).

Evi FR menambahkan bahwa pada mulanya pilot project KKN literasi ini adalah mahasiswa Fakultas Tarbiyah yang kemudian juga melibatkan mahasiswa dari fakultas lainnya. Sebelum KKN dilakukan placement test untuk mengukur kepribadian mahasiswa (ekstrovert atau introvert) demi membagi proporsional tim. Tiap kelompok yang dibentuk kemudian dibimbing dengan pembekalan program literasi.

Mahasiswa yang menjalankan KKN literasi ini juga dapat mengembangkan kreasinya selama masih terkait dengan literasi.

\begin{abstract}
"Selain menjalankan target utama KKN (aplikasi literasi dan managerial perpustakaan), mahasiswa dapat melakukan pengembangan lainnya, dimungkinkan di lokasi KKN mahasiswa melakukan pendampingan pers madrasah, misalnya dari anak dakwah yang memiliki background desain grafis akan sangat membantu madrasah. Proporsi mahasiswa (Fakultas) Tarbiyah dan (Fakultas) Dakwah mensuplai desain pers, sedangkan Tarbiyah dan Dakwah dapat mensuplai bagian konten." (Wawancara dengan Evi FR pada 17 Mei 2018).
\end{abstract}

\title{
Literasi Pers UIN Sunan Ampel
}

Warna literasi di UINSA selain dapat dirunut dari Perpustakaan dan LP2M, dapat pula dilihat dari Pers Mahasiswa, yang akan dideskrespikan lebih lanjut, dan sisanya merupakan petikanpetikan literasi yang ditemukan lainnya. Beberapa kegiatan literasi lain yang diselenggarakan UINSA di antaranya seperti lomba mading log, duta baca, bedah buku, kelas literat, dan masih banyak lagi. 
Pers mahasiswa UINSA terbagi ke dalam dua kelompok besar, yaitu ada satu UKM pers tingkat Universitas yang bernama Solidaritas, dan pers di masing-masing fakultas. Berikut adalah data Lembaga Pers Mahasiswa di UINSA:

Tabel 6. Nama-nama LPM UINSA

\begin{tabular}{lll}
\hline & Nama LPM & Web \\
\hline Universitas & Solidaritas & $\begin{array}{l}\text { https://www.solidaritas-uinsa.org/ } \\
\text { https://mediasolidaritas.com/ }\end{array}$ \\
\hline Fakultas & & \\
\hline
\end{tabular}

(1) Adab dan Humaniora Qimah https://deskgram.org/lpm_qimah

(2) Dakwah dan Ara Aita http://www.araaita.com/

Komunikasi

\begin{tabular}{lll}
\hline (3) Tarbiyah dan & Edukasi http://www.edukasipers.org/ \\
Keguruan & & \\
\hline
\end{tabular}

(4) Ushuludin dan $\quad$ Forma http://www.formasurabaya.com/
Filsafat

(5) Syariah dan Hukum Arrisalah arrisalah (perbaikan)

(6) Sains dan Teknologi Riset

(7) Ekonomi dan Bisnis Almaslahah http://almaslahah.org/ Islam

(8) Ilmu Sosial dan Ilmu Parlemen https://lpmparlemen.wordpress.com/ Politik

(9) Psikologi Alam Tara http://www.alamtarapersma.com/

Sumber: data peneliti

LPM Solidaritas berkantor di Ruang Aktivitas Kemahasiswaan Lt. 1 Ruang No. 10 UIN Sunan Ampel Jl. Ahmad Yani 117, Surabaya, 60237. LPM ini didirikan apda 31 Januari 2001 di Surabaya, sedangkan proses penerbitannya sudah dimulai sejak tanggal 24 April 1991. Visi LPM Solidaritas adalah sebagai garda depan perubahan, sedangkan misinya adalah mendorong terbentuknya masyarakat kritis dan transformatif, melakukan pembelaan pada kaum tertindas melalui kerja-kerja jurnalistik, melakukan fungsi kontrol bagi terbentuknya sistem yang demokratis (LPM-Solidaritas 2017). 
Wilayah kerja yang juga merupakan produk LPM Solidaritas di antaranya; 1) penerbitan tabloid solidaritas; 2) penerbitan koran beranda; 3) penerbitan buletin coret; 4) media online; 5) pelatihan jurnalistik; 6) kajian ilmiah; dan 7) usaha-usaha lain yang mendukung internal dan eksternal lembaga (LPM Solidaritas, 2017: 11).

Produk LPM Solidaritas dapat dijabarkan lebih jauh sebagai berikut (LPM Solidaritas, 2017: 16-17).

1. Tabloid Solidaritas, merupakan media utama LPM Solidaritas yang mengulas fenomena sosial yang dikemas secara ilmiah akademis dengan durasi terbit minimal 2 kali dalam 1 periode kepengurusan.

2. Koran Beranda, merupakan media berbentuk koran yang mengulas persoalan dalam kampus UIN Sunan Ampel Surabaya dengan durasi terbit minimal 2 kali dalam 1 periode kepengurusan.

3. Buletin Coret, merupakan wahana kreasi dan aspirasi bagi calon maganger (anggota LPM baru di tahun pertama dan kedua), sebagai pengembangan kerja jurnalistik.

4. Media Online yang terdiri dari website (solidaritas-uinsa.org dan mediasolidaritas.com) berisi karya jurnalistik anggota LPM Solidaritas, karya sastra, opini, esai, serta resensi. Pengelolaan dan pengembangan website Solidaritas melalui publikasi tulisan dan karya jurnalistik. Durasi terbit minimal 3 tulisan dalam seminggu.

5. Media Sosial, terdiri Twitter: @LPMSolidaritas; Instagram: @1pmsolidaritas@solidaritasfoto; Line:@wxb1452b; Facebook:

Tabel 7. Deskripsi terbitan LPM Solidaritas

\begin{tabular}{llll}
\hline Deskripsi & Tabloid Solidaritas & Koran Beranda & Buletin Coret \\
\hline Durasi Terbit & 2 x setahun & 2 x setahun & $1 \times$ sebulan \\
\hline $\begin{array}{l}\text { Jumlah } \\
\text { Halaman }\end{array}$ & $24 \mathrm{hlm}$. & $16 \mathrm{hlm}$. & $4 \mathrm{hlm}$. \\
\hline
\end{tabular}




\begin{tabular}{|c|c|c|c|}
\hline Rubrikasi & $\begin{array}{l}\text { 1. Halaman sampul } \\
\text { 2. Minna dan } \\
\text { Minkum (Salam } \\
\text { sapa redaktur dan } \\
\text { pembaca.) } \\
\text { 3. Editorial } \\
\text { 4. Fokus } 1 \text { (artikel } \\
\text { berita) } \\
\text { 5. Fokus } 2 \text { (liputan } \\
\text { berita) } \\
\text { 6. Fokus } 3 \text { (artikel) } \\
\text { 7. Fokus } 4 \text { (artikel } \\
\text { berita) } \\
\text { 8. Fikroh (artikel) } \\
\text { 9. Sorot } 1 \text { (liputan) } \\
\text { 10. Sorot } 2 \text { (liputan) } \\
\text { 11. Sorot } 3 \text { (liputan) } \\
\text { 12. Lepas (artikel luar) } \\
\text { 13. Visi (artikel) } \\
\text { 14. Resensi } \\
\text { 15. PISS (liputan) } \\
\text { 16. Telaah } 1 \text { (artikel) } \\
\text { 17. Telaah } 2 \text { (data } \\
\text { polling) } \\
\text { 18. Rihlah (kajian } \\
\text { tokoh) } \\
\text { 19. Ibroh (liputan) } \\
\text { 20. Lontar (artikel) } \\
\text { 21. Pretz (dokumentasi) } \\
\text { 22. Sampul belakang } \\
\text { (iklan) }\end{array}$ & $\begin{array}{ll}\text { 1. } & \text { Halaman } \\
\text { depan (berita } \\
\text { utama) } \\
\text { 2. Editorial } \\
\text { 3. } \begin{array}{l}\text { Khobar } \\
\text { (liputan } \\
\text { berita) }\end{array} \\
\text { 4. Opini } \\
\text { 5. Sosok (liputan } \\
\text { tokoh } \\
\text { kampus) } \\
\text { 6. Celoteh (surat } \\
\text { pembaca) } \\
\text { 7. Telusur } \\
\text { (polling isu) } \\
\text { 8. Resensi buku } \\
\text { 9. Sastra (puisi) } \\
\text { 10. Tabir (tanya } \\
\text { birokrat) }\end{array}$ & $\begin{array}{l}\text { 1. Halaman } \\
\text { depan berita } \\
\text { utama } \\
\text { 2. Halaman dua } \\
\text { berita turunan } \\
\text { dari topik } \\
\text { utama } \\
\text { 3. Halaman tiga } \\
\text { berita selingan } \\
\text { dari topik } \\
\text { 4. Halaman } \\
\text { empat: celoteh }\end{array}$ \\
\hline
\end{tabular}

\section{LPM Solidaritas; dan Fan page: LPM Solidaritas}

Deskripsi dari tabloid, koran, dan buletin dari LPM Solidaritas, dapat dilihat pada tabel berikut.

Kegiatan LPM Solidaritas dapat berjalan dengan adanya dana. Sumber pendanaan LPM Solidaritas berasal dari; 1) daftar isian pelaksanaan anggaran UINSA; 2) iklan; 3) bantuan lain yang tidak mengikat; dan 4) proyek kerjasama dengan lembaga atau individu lain yang tidak melanggar aturan LPM (LPM Solidaritas, 2017: 13).

Beberapa aktivitas literasi selain produk di atas yang dilakukan LPM Solidaritas adalah festival jurnalistik dengan pemateri dari luar. LPM Solidaritas sebenarnya memimpikan untuk dapat 
menerbitkan buku, akan tetapi untuk mencapai hal itu masih sulit, seperti yang diungkap ketua LPM Solidaritas berikut.

\begin{abstract}
"Untuk penerbitan buku sementara dalam program kerja kami belum ada. Penerbitan sekarang ini langsung satu pintu di lembaga percetakan kampus, hasilnya kalau mau cepat hitam putih, untuk warna bisa antri lama. Penerbit/percetakan ini sbuk sekali, pegawainya juga terbatas (semacam foto kopi yang jadi bagian dari kampus). Meskipun demikian, untuk produk dua edisi dalam setahun tetap ada yang cetak, karena itu sudah termasuk dalam pengeluaran SPP kampus, sehingga mahasiswa menerima gratis. Adapun dalam web, kami bisa lebih bebas" (Wawancara dengan Wiji dan Riski, 21 Mei 18).
\end{abstract}

Tidak jauh berbeda dengan pers di tingkat Universitas, pers di tiap Fakultas juga memiliki kepengurusan dan sistem kerja yang terstruktur. Masing-masing pers berlomba menampilkan kreasi mereka baik dalam bentuk buletin, laman web, maupun majalah. Hasil observasi penulis memberikan gambaran bahwa pers Fakultas Dakwah tampak sangat produktif. Beberapa data tambahan menarik terkait literasi di tingkat Fakultas oleh mahasiswa dari hasil FGD 24 Mei 2018 tampak dalam kutipan berikut.

\begin{abstract}
"Majalah dan buletin adalah Ara aita. Kondisi perpustakaan Fakultas standar saja, terutama menyediakan referensi Fakultas Dakwah, kadangkala kami juga butuh ke Perpustakaan Pusat. Iklim literasi terhadap buku cetak, baik di Perpus misalnya, masih perlu ditingkatkan" (NM, Smt 6, Fak. Dakwah).
\end{abstract}

"LPM Ushuludin adalah Forma. Majalah itu terbit dua kali dalam setahun. Buletin ada mingguan hanya untuk sementara ini media (buletin) cetak semakin lesu. Akan tetapi, webnya masih terus aktif, terutama sejak akhir 2016. Perpustakaan kurang tertata, sementara ini sering ke perpustakaan pusat untuk mencari buku. Sebenarnya setiap hari ramai perpustakaan, tidak hanya untuk mencari referensi, tetapi juga untuk berdiskusi dan mengerjakan tugas" (N, Smt 4, Fak. Ushuluddin).

"LPM Al Maslahah. Web juga termasuk baru dibanding yang lain, baru 2 tahunan, jadi sementara produknya hanya lewat web. Perpustakaan ekonomi, sedang dikerjakan, sebenarnya ruang dan koleksinya sudah 
ada, tetapi belum diresmikan dan dibuka sebagai perpustakaan, sepertinya tahun depan. Jadi untuk sementara berkunjung ke perpustakaan di pusat" (FD, Fak. Ekonomi Bisnis).

Kondisi web dari masing-masing LPM tiap fakultas belumlah lama, meskipun demikian, embrio dari majalah maupun buletin sudah ada jauh sebelumnya. Tampilan web tiap LPM masih terus berbenah dan berkembang. Pembiasaan dari literasi cetak ke literasi web juga masih dalam taraf penyesuaian.

\section{Praktik Literasi Mahasiswa UIN Sunan Ampel}

Melalui kuesioner google form kepada 267 responden dan wawancara purposif kepada beberapa perwakilan mahasiswa pers Fakultas, terkumpul data terkait sembilan aspek praktik literasi yang sudah disebutkan di awal meliputi topik, gaya dan genre, mode dan teknologi, tujuan, fleksibilitas dan kendala, aksi dan proses, audiens, peran dan indentitas, serta interaksi dan kolaborasi.

\section{Gambar 5}

Sebaran kuesioner

\section{Sebaran Kuesionor per-Fakultas: 267 Responden}

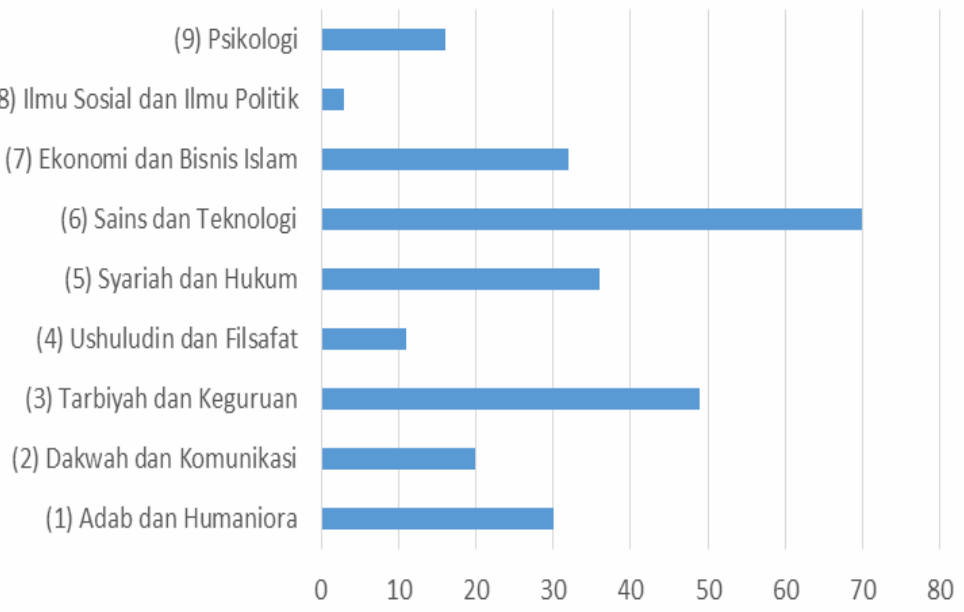




\section{Literasi Membaca}

Membaca menjadi kemampuan dasar literasi, membaca yang dalam arti sebagai kebutuhan bukan paksaan, sehingga menimbulkan kesan senang. Kecenderungan mahasiswa UINSA baru tahap cukup senang (63\%), sedangkan yang sangat senang/ menikmati baru $35 \%$.

\section{Gambar 6}

Kesenangan membaca

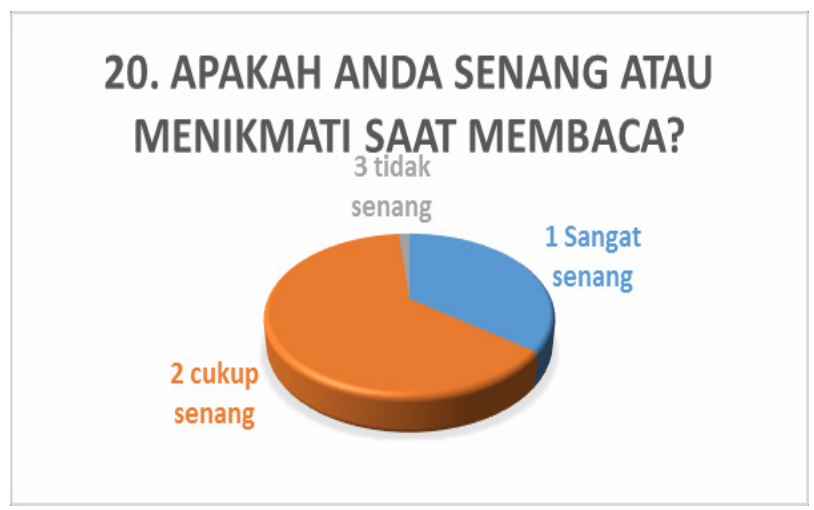

Saat membaca sudah mengarah kepada hobi atau kebutuhan, maka dapat diihat pula dalam kegiatan mahasiswa di luar kampus. Ada $24 \%$ mahasiswa yang mengaku terbiasa membaca setiap hari, $42 \%$ membaca sekali dua dalam semingu.

\section{Gambar 7}

Membaca di luar kampus

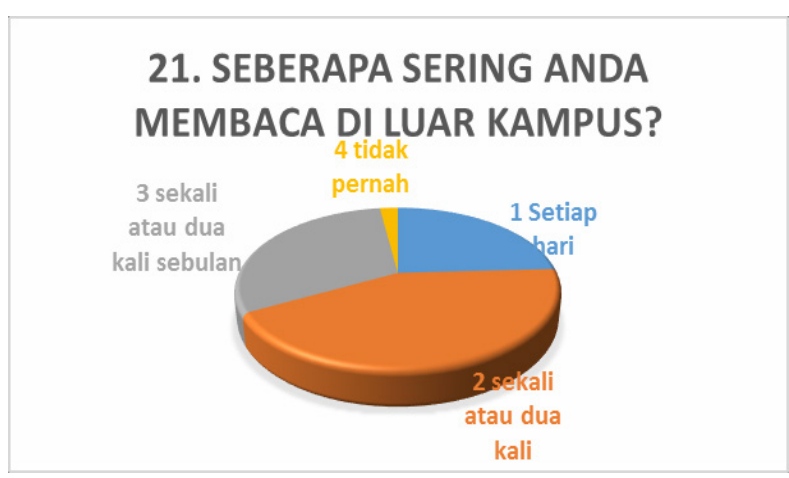


Tujuan membaca sangat beragam, demikian pula dengan mahasiswa UINSA. Kecenderungan mereka sudah menyatakan bahwa yang utama dari membaca adalah dapat membuka wawasan (59 \%).

\section{Gambar 8}

Tujuan membaca

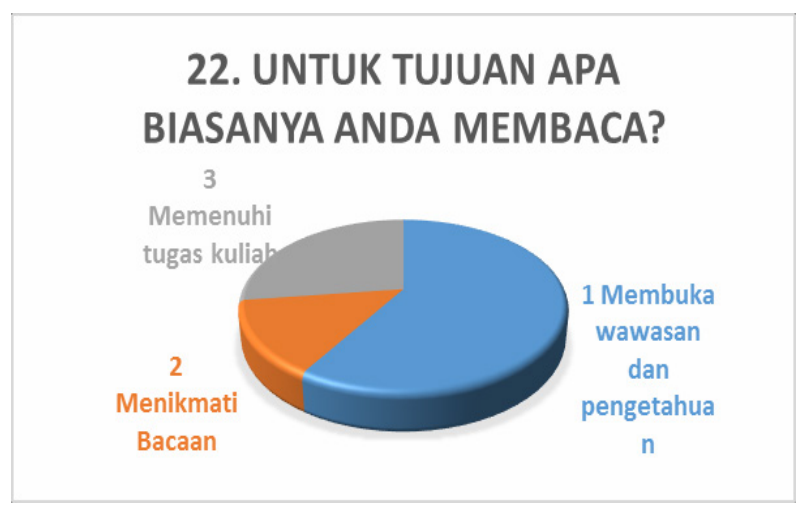

Beberapa sikap yang penulis tanyakan kepada mahasiswa terkait kegiatan membaca dapat dilihat dalam tabel berikut.

Tabel 8. Kegiatan membaca mahasiswa

\begin{tabular}{lll}
\hline Pernyataan & Setuju & $\begin{array}{l}\text { Tidak } \\
\text { setuju }\end{array}$ \\
\hline $\begin{array}{l}\text { 23. Saya membaca karena membaca adalah keahlian atau } \\
\text { keterampilan yang harus dimiliki dalam hidup. }\end{array}$ & $91 \%$ & $9 \%$ \\
\hline $\begin{array}{l}\text { 24. Membaca membantu saya menemukan sesuatu yang } \\
\text { saya ingin ketahui. }\end{array}$ & $100 \%$ & $0 \%$ \\
\hline $\begin{array}{l}\text { 25. Saya merasa terhibur dengan membaca. } \\
\begin{array}{l}\text { 26. Saya akan lebih banyak membaca ketika saya } \\
\text { menikmati bacaan yang saya baca. }\end{array}\end{array}$ & $91 \%$ & $9 \%$ \\
\hline $\begin{array}{l}\text { 27. Kebiasaan membaca dapat membantu saya dalam } \\
\text { mendapatkan pekerjaan. }\end{array}$ & $78 \%$ \\
\hline $\begin{array}{l}\text { 28. Kebiasaan membaca mengajarkan saya memahami } \\
\text { orang lain. }\end{array}$ & $82 \%$ \\
\hline $\begin{array}{l}\text { 29. Kebiasaan membaca dapat membantu mengenali diri } \\
\text { saya sendiri. }\end{array}$ & $88 \%$ & $12 \%$ \\
\hline
\end{tabular}


30. Saya hanya membaca jika ada tugas kuliah yang harus $\quad 32 \% \quad 68 \%$ diselesaikan.

31. Saya selalu menyempatkan waktu untuk membaca. $\quad 69 \% \quad 31 \%$

Kegiatan membaca mahasiswa juga dapat dipengaruhi oleh situasi dan kondisi tertentu atau faktor eksternal mahasiswa, yang di antaranya dapat dilihat dalam tabel berikut.

Tabel 9. Faktor eksternal membaca

\begin{tabular}{|c|c|c|}
\hline Pernyataan & Setuju \% & $\begin{array}{l}\text { Tidak } \\
\text { Setuju \% }\end{array}$ \\
\hline $\begin{array}{l}\text { 33. Saya akan lebih banyak membaca jika buku bacaan } \\
\text { harganya lebih murah. }\end{array}$ & 65 & 35 \\
\hline $\begin{array}{l}\text { 34. Saya akan lebih banyak membaca jika bacaannya } \\
\text { lebih banyak gambar atau ilustrasi. }\end{array}$ & 71 & 29 \\
\hline $\begin{array}{l}\text { 35. Saya akan lebih banyak membaca jika telah } \\
\text { mengetahui topik dari bacaan yang akan saya baca. }\end{array}$ & 89 & 11 \\
\hline $\begin{array}{l}\text { 36. Saya akan lebih banyak membaca jika perpustakaan } \\
\text { di kampus lebih baik fasilitas dan koleksinya. }\end{array}$ & 82 & 18 \\
\hline $\begin{array}{l}\text { 37. Saya akan lebih banyak membaca jika menemukan } \\
\text { bacaan yang mudah dibaca, tidak membuat saya } \\
\text { pusing dan bingung. }\end{array}$ & 90 & 10 \\
\hline $\begin{array}{l}\text { 38. Saya akan lebih banyak membaca jika teman saya } \\
\text { banyak membaca juga. }\end{array}$ & 40 & 60 \\
\hline $\begin{array}{l}\text { 39. Saya akan lebih banyak membaca jika kampus atau } \\
\text { dosen mendorong saya untuk membaca. }\end{array}$ & 61 & 39 \\
\hline $\begin{array}{l}\text { 40. Saya akan membaca lebih banyak jika keluarga } \\
\text { saya (ayah, ibu dan saudara) mendorong saya untuk } \\
\text { membaca. }\end{array}$ & 60 & 40 \\
\hline $\begin{array}{l}\text { 41. Saya akan lebih banyak membaca jika ada seseorang } \\
\text { (teman) yang mendorong saya untuk membaca. }\end{array}$ & 58 & 42 \\
\hline 42. Membaca hanya untuk orang pintar. & 3 & 97 \\
\hline 43. Membaca itu membosankan. & 19 & 81 \\
\hline 44. Membaca itu susah. & 13 & 87 \\
\hline 45. Membaca itu penting. & 99 & 1 \\
\hline 46. Tidak ada bacaan yang menarik untuk saya. & 4 & 96 \\
\hline
\end{tabular}




\begin{tabular}{lll}
\hline 47. Buku bisa sebagai hadiah. & 97 & 3 \\
\hline $\begin{array}{l}\text { 48. Saya lebih suka membaca bacaan dalam bentuk } \\
\text { digital (misalnya buku, koran, majalah elektronik } \\
\text { dan/atau pdf). }\end{array}$ & 56 & 44 \\
\hline
\end{tabular}

Mayoritas mahasiswa menyatakan bahwa mereka terbiasa mendiskusikan hasil bacaan kepada orang lain (73\%). Di antara mereka cenderung mengajak diskusi teman sebaya (64\%), baru sisanya kepada orang dekat seperti keluarga, orang tua, atau suami/isteri. Hanya sedikit dari mereka yang mempunyai ide membagi hasil bacaan dalam bentuk tulisan di laman web mereka.

Baru sedikit mahasiswa yang mengaku mengalokasikan uang mereka untuk membeli buku (33\%). Dukungan dari orang tua/ keluarga mahasiswa yang memberikan jatah rutin bagi mereka membeli buku masih sedikit (11\%).

Kecenderungan mahasiswa masih menyukai genre bacaan fiksi $(61 \%)$. Tema fiksi yang mereka pilih beragam: romantis $(28$ $\%)$, komedi (22\%), kepahlawanan (17\%), religi (15\%), kriminal (7\%), dan horor (6\%). Tema nonfiksi yang mereka pilih: sains teksnologi (30\%), agama (24\%), sosial kebudayaan (22\%), sejarah (15\%), dan filsafat (5\%).

Adapun kecenderungan tema non-fiksi keagamaan yang disenangi mahasiswa UINSA terlihat dalam gambar berikut.

\section{Gambar 9}

Kecenderungan pilihan tema non fiksi keagamaan

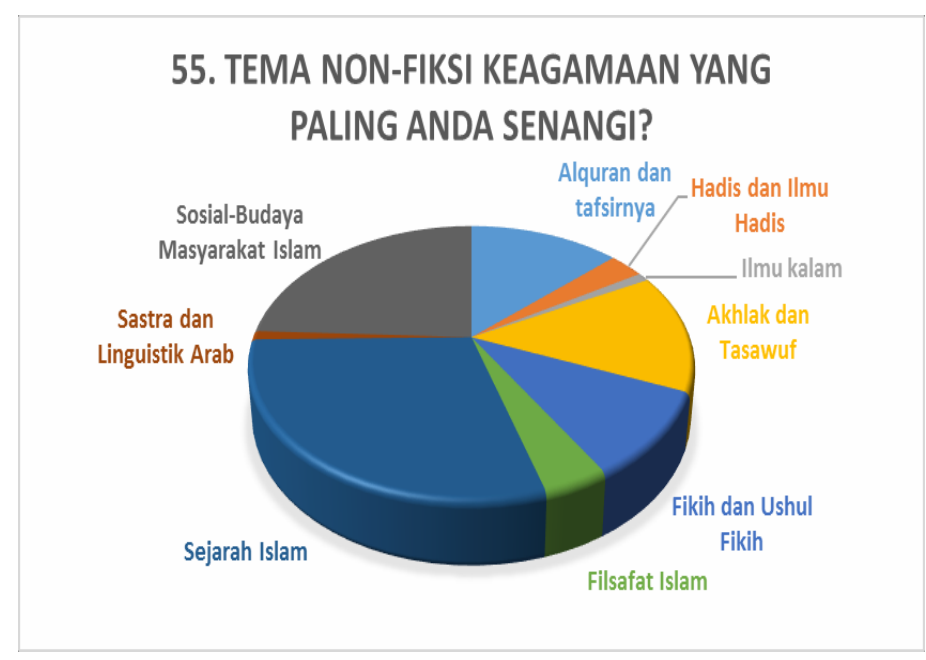


Kecenderungan mahasiswa menyatakan bahwa kondisi perpustakaan UINSA sudah nyaman untuk membaca (64\%). Intensitas kunjungan mahasiswa dalam tiap minggunya beragam, hanya $4 \%$ yang menyatakan berkunjung ke perpustakaan tiap hari, $19 \%$ menyatakaan tiga kali seminggu, $45 \%$ menyatakan hanya seminggu sekali ke perpustakaan, dan masih tergolong banyak yang jarang/ bahkan tidak megenal perpustakaan sebanyak $31 \%$.

Selain untuk tujuan membaca dan meminjam buku, kecenderungan mahasiswa berkunjung ke perpustakaan adalah untuk mengerjakan tugas (79 \%), berdiskusi (5\%), atau bertemu teman (5\%), dan sisanya untuk tujuan lain-lain (11\%) baik untuk sekedar berkunjung, melihat-lihat, beristirahat, atau hal lainnya.

Bagi mahasiswa UINSA, hal yang menghambat mereka membaca adalah sulitnya mendapatkan bacaan yang menarik (35\%). Bagi mereka bacaan-bacaan yang ada (di lingkungan perpustakaan kampus) adalah bacaan yang membosankan (41 $\%)$. Banyak pula dari mereka yang memberikan alasan tidak punya dana khusus untuk membeli bahan bacaan baik buku, koran, atau majalah (16 \%). Sedangkan sisanya, meskipun kecil (7\%) menyatakan karena mereka memang tidak (terlalu) suka membaca.

\section{Literasi Menulis}

Separuh lebih responden menyatakan bahwa mereka senang menulis (58\%). Meskipun demikian, mereka menyatakan bahwa mereka memiliki kendala saat menulis terutama pada tiga hal: menemukan ide (42\%), menuliskan dalam kalimat (38\%), dan mencari referensi (19\%). Beberapa kondisi terkait menulis mahasiswa dapat dilihat dalam tabel berikut. 
Tabel 10. Kondisi menulis mahasiswa

\begin{tabular}{lll}
\hline $\begin{array}{l}\text { Pernyataan } \\
\begin{array}{l}\text { 62. Saya akan menulis dengan baik jika dosen memberikan } \\
\text { tugas membuat makalah. }\end{array}\end{array}$ & $\begin{array}{c}\text { setuju } \\
\%\end{array}$ & $\begin{array}{c}\text { tidak } \\
\text { setuju \% }\end{array}$ \\
\hline $\begin{array}{l}\text { 63. Menulis dapat membantu saya mengekspresikan ide } \\
\text { saya. }\end{array}$ & 94 & 6 \\
\hline $\begin{array}{l}\text { 64. Jika tidak ada tugas menulis dari dosen, saya tidak } \\
\text { menulis apapun. }\end{array}$ & 36 & 63 \\
\hline $\begin{array}{l}\text { 65. Menulis itu susah. } \\
\text { 66. Menulis itu menyenangkan. }\end{array}$ & 44 & 56 \\
\hline $\begin{array}{l}\text { 67. Saya lebih senang menulis tulisan fiksi. } \\
\text { 68. Saya lebih senang menulis tulisan non-fiksi. }\end{array}$ & 61 & 26 \\
\hline
\end{tabular}

Tabel 10 memberikan gambaran pula bahwa sebenarnya mahasiswa UINSA sudah mengenal kebiasan menulis sama dengan kebiasaan membaca, hanya saja tingkat keaktifan mereka yang beragam, ada yang masih memerlukan stimulus dari luar seperti kebutuhan diberi tugas oleh pihak kampus. Dengan demikian, dukungan dari pihak luar masih memiliki pengaruh terhadap keaktifan mahasiswa dalam menulis.

Pengalaman menulis mahasiswa UINSA beragam. Beberapa dari mereka mengaku sudah terbiasa menulis di media baik di web maupun media cetak ( $25 \%$ ). Terkait membaca dan menulis dengan tema keagamaan, mahasiswa juga mengakses internet yang intensitasnya beragam: ada yang setiap hari (27\%), 1-3 kali seminggu (26\%), seminggu sekali (16\%), 1-3 kali sebulan (14\%), dan 1 bulan sekali (10\%).

Saat mereka mengakses informasi keagamaan, $33 \%$ dari mereka mengaku bahwa data mereka terkait dengan mata kuliah kampus, $24 \%$ menyatakan tidak terkait dengan mata kuliah kampus, dan sisanya $41 \%$ ragu-ragu.

Informasi di internet yang berlimpah di satu sisi rawan akan hoax, maka dari itu mahasiswa UINSA juga sedikit banyak mengetahuinya. $85 \%$ dari mereka menyatakan cenderung akan mencari informasi pembanding saat menemukan informasi kegamaan ataupun informasi lainnya dari internet. 
Terkait bacaan keislaman, penulis memberikan pertanyaan sikap para mahasiswa kepada contoh para penulis yang sudah dikenal dengan klasifikasinya masing-masing. Terlepas dari tingkat validitas datanya, masih banyak mahasiswa yang belum mengenal contoh penulis yang disajikan, seperti tampak dalam tabel 11. Data awal ini juga akan menarik untuk dilanjutkan terkait kecenderungan tokoh yang diikuti atau ditolak mahasiswa maupun mengukur tingkat moderasi keagamaan/islamisme mahasiswa UINSA seperti yang dilakukan pengkaji sebelumnya (Kailani 2018).

Tabel 11. Sikap terhadap tokoh penulis

\begin{tabular}{|c|c|c|c|c|}
\hline No & Tokoh/Penulis & Setuju \% & Tidak Setuju \% & Tidak Tahu \% \\
\hline 1 & Abul A'la Al-Maududi & 27 & 6 & 66 \\
\hline 2 & Sayyid Qutb & 34 & 8 & 58 \\
\hline 3 & Hasan Al-Bana & 39 & 6 & 55 \\
\hline 4 & Fazlur Rahman & 27 & 8 & 65 \\
\hline 5 & Aidh Al-Qarni & 26 & 9 & 65 \\
\hline 6 & $\begin{array}{l}\text { Ibnu Qayyim Al- } \\
\text { Jauziyah }\end{array}$ & 35 & 7 & 58 \\
\hline 7 & Ibnu Qayyim AlJauziyah & 36 & 6 & 57 \\
\hline 8 & Harun Nasution & 42 & 7 & 50 \\
\hline 9 & $\begin{array}{l}\text { Abdurrahman Wahid (Gus } \\
\text { Dur) }\end{array}$ & 71 & 4 & 24 \\
\hline 10 & Nurcholish Madjid (Cak Nur) & 47 & 7 & 46 \\
\hline 11 & $\begin{array}{l}\text { Emha Ainun Nadjib (Cak } \\
\text { Nun) }\end{array}$ & 68 & 4 & 28 \\
\hline 12 & Said Aqil Siradj & 36 & 10 & 53 \\
\hline 13 & Jalaluddin Rahmat & 29 & 9 & 61 \\
\hline 14 & M. Quraish Shihab & 62 & 7 & 30 \\
\hline 15 & Felix Siauw & 42 & 16 & 42 \\
\hline 16 & Taqiyuddin Al-Nabhani & 24 & 13 & 63 \\
\hline 17 & Habiburrahman Al-Shirazi & 56 & 6 & 39 \\
\hline 18 & Helvy Tiana Rosa & 23 & 11 & 66 \\
\hline 19 & Asma Nadia & 61 & 7 & 32 \\
\hline
\end{tabular}


Tabel 11 menunjukkan bahwa untuk nama-nama tokoh yang terkenal secara nasional dan cenderung moderat disukai oleh mahasiswa semisal (Cak Nun, Gus Dur, dan M Quraish Shihab). Meskipun demikian, tokoh-tokoh muslim transnasional juga tidak dikatakan sedikit dikenal, meskipun jika dibuat rata-rata belum ada separuh dari responden yang mengenal, terlebih setuju dengan pemikiran mereka, oleh karenanya dapat dikaji lebih jauh. Selanjutnya, tokoh muslim muda yang produktif (seperti Habiburrahman dan Asma Nadia) juga sudah akrab di kalangan mahasiswa UINSA.

\section{Formula menuju Kampus Literat}

Usaha mewujudkan kondisi kampus UINSA yang literat tidak lepas dari peran faktor internal berupa kekuatan dan kelemahan. Dari data yang telah dipaparkan sebelumnya, kekuatan dan kendala literasi di kampus UINSA dapat dirinci secara garis besar sebagai berikut.

Tabel 12. Kekuatan dan kelemahan Literasi UINSA

\begin{tabular}{|c|c|c|}
\hline No & Kekuatan & Kelemahan \\
\hline 1. & $\begin{array}{l}\text { UINSA memiliki paradigma } \\
\text { keilmuan integrated tein-tower yang } \\
\text { melambangkan keseimbangan } \\
\text { antara keilmuan umum dan } \\
\text { keilmuan agama yang diharapkan } \\
\text { menghasilkan generasi ulul albab. }\end{array}$ & $\begin{array}{l}\text { Civitas akademi UINSA masih } \\
\text { berproses untuk mengikuti } \\
\text { paradigma ini sehingga } \\
\text { masih dimungkinkan terjadi } \\
\text { ketidakseimbangan dua keilmuan } \\
\text { yang diharapkan. }\end{array}$ \\
\hline 2 & $\begin{array}{l}\text { Kurikulum UINSA mengacu } \\
\text { kurikulum KKNI yang aplikasinya } \\
\text { tiap prodi dapat menyusun } \\
\text { kurikulum sendiri sesuai } \\
\text { kebutuhan. }\end{array}$ & $\begin{array}{l}\text { Keberhasilan kurikulum yang } \\
\text { disusun sendiri sangat dipengaruhi } \\
\text { oleh SDM UINSA yang dimiliki tiap } \\
\text { prodi, dan masih berproses. }\end{array}$ \\
\hline 3 & $\begin{array}{l}\text { Dalam mendukung literasi, } \\
\text { UINSA didukung dengan adanya } \\
\text { perpustakaan pusat dan fakultas. } \\
\text { Perpustakaan pusat didukung } \\
\text { dengan beridirinya gedung megah } \\
\text { tiga lantai dengan berbagai fasilitas. } \\
\text { Koleksi bacaan yang dimiliki juga } \\
\text { terus berkembang baik bentuk } \\
\text { cetak atau soft copy, baik offline } \\
\text { maupun online. }\end{array}$ & $\begin{array}{l}\text { Hal yang dapat dianggap kelemahan } \\
\text { dalam perpustakaan UINSA yang } \\
\text { ditemukan antara lain: a) masih } \\
\text { dalam proses dari perpustakaan } \\
\text { dengan koleksi keilmuan yang } \\
\text { lebih condong ke referensi Islami } \\
\text { ke referensi dua keilmuan yang } \\
\text { berimbang; b) jumlah kunjungan } \\
\text { dan peminjaman masih perlu } \\
\text { dipacu. }\end{array}$ \\
\hline
\end{tabular}


$4 \quad$ Literasi UINSA juga didukung peran LP2M terutama dalam penyelenggaraan kuliah kerja nyata (KKN) yang dapat mengusung sistem tematik misalnya KKN Literasi.
KKN Literasi masih bersifat pengembangan sektoral yang dimotori dari fakultas tarbiyah.
$5 \quad$ Literasi umum UINSA dapat diwakili oleh adanya pers mahasiswa baik pusat ataupun per fakultas yang sudah berjalan sejak kampus berdiri.

\author{
Sumber pendanaan dan dukungan \\ dari pihak kampus masih dirasa \\ kurang oleh mahasiswa
}

Selain faktor internal yang berpengaruh pada kondisi kampus UINSA yang literat terdapat pula peran faktor eksternal berupa peluang dan tantangan yang dapat dirinci garis besarnya sebagai berikut.

Tabel 13. Peluang dan tantangan literasi UINSA

\begin{tabular}{|c|c|c|}
\hline No & Peluang & Tantangan \\
\hline 1. & $\begin{array}{l}\text { Adanya peraturan } \\
\text { perundangan pemerintah } \\
\text { yang mendukung terciptanya } \\
\text { kondisi literat }\end{array}$ & $\begin{array}{l}\text { Dukungan peraturan pemerintah } \\
\text { terhadap literasi masih } \\
\text { memerlukan peran mandiri dari } \\
\text { pihak kampus }\end{array}$ \\
\hline 2 & $\begin{array}{l}\text { Adanya komitmen dari civitas } \\
\text { akademika untuk berproses } \\
\text { maju menciptakan kondisi } \\
\text { literat }\end{array}$ & $\begin{array}{l}\text { Komitmen civitas akademik } \\
\text { terhadap perlu terus dibangun } \\
\text { dan diaplikasikan dari konsep ke } \\
\text { pelaksanaan }\end{array}$ \\
\hline 3 & $\begin{array}{l}\text { Perpustakaan akan terus } \\
\text { berkembang mengikuti } \\
\text { perkembangan dan } \\
\text { tuntutan literat }\end{array}$ & $\begin{array}{l}\text { Untuk mengikuti perkembangan } \\
\text { dan tuntutan literasi } \\
\text { memerlukan kecakapan SDM } \\
\text { dan sarana prasarana }\end{array}$ \\
\hline 4 & $\begin{array}{l}\text { Perkembangan ilmu } \\
\text { pengetahuan dan teknologi } \\
\text { akan memberikan peluang } \\
\text { peningkatan literasi keilmuan } \\
\text { global }\end{array}$ & $\begin{array}{l}\text { Perkembangan iptek juga selalu } \\
\text { memiliki sisi negatif yang patut } \\
\text { dicermati }\end{array}$ \\
\hline
\end{tabular}


Setelah memetakan faktor internal dan eksternal yang berpengaruh sebagaimana disebutkan sebelumnya, maka dapat disusun strategi SWOT mengusahakan terwujudnya kondisi kampus UINSA yang literat.

1. Perlu dilakukan sinergi berbagai pihak dari civitas akademika untuk meningkatkan literasi sebagai kebutuhan dasar. Pihak pusat perlu memberikan perhatian dan dukungan dana yang signifikan kepada motor penggerak literasi baik perpustakaan, LP2M, maupun lembaga pers mahasiswa.

2. Perlu dibuat program lebih masif gerakan literasi sederhana seperti wajib berkunjungpinjam di perpustakaan, membaca, dan menulis baik oleh dosen maupun mahasiswa.

3. Perlu dilakukan evaluasi periodik dari berbagai pihak untuk terus meningkatkan literasi, seperti menanggapi aspirasi dari mahasiswa dan pihak civitas akademika yang di antaranya tertangkap dalam temuan kajian ini.

\section{Penutup}

Dunia pendidikan Indonesia memang sedang menggaungkan program literasi, dari literasi dasar baca tulis hingga literasi tingkat lanjut berupa produksi dari hasil literasi. Kajian literasi dasar ini setidaknya dapat mendeskripsikan lebih banyak kondisi faktual dari praktik literasi yang terjadi di kampus UINSA Surabaya. Kondisi perpustakaan yang barangkali dianggap baik-baik saja, ternyata masih menyimpan pekerjaan rumah dalam meningkatkan tingkat kunjungan. Dari hasil kuesioner misalnya dapat diketahui bahwa mahasiswa membutuhkan interaksi dan dorongan dari luar dirinya (dosen, keluarga, dan teman sebaya) untuk meningkatkan minat literasi mereka, dan masih banyak lagi.

Konsep sembilan aspek praktik literasi yang digagas Edward yang diterapkan dalam kajian ini cukup mampu membantu pengkaji dalam memetakan kondisi literasi mahasiswa. Meskipun 
demikian, bisa jadi pendekatan ini masih belum bisa menyeluruh dalam menggali lebih banyak data. Demikian pula analisis SWOT yang diterapkan, bisa jadi masih belum sempurna dan belum memberikan rumusan strategi yang aplikatif. Oleh karena itu, kajian lanjutan masih sangat terbuka untuk dilakukan.

\section{DAFTAR PUSTAKA}

Antoro, Billy. 2017. Gerakan Literasi Sekolah: Dari Pucuk Hingga Akar. 1st ed. Jakarta: Direktorat Jenderal Pendidikan Dasar dan Menengah Kementerian Pendidikan dan Kebudayaan. https:// doi.org/10.1017/S0033291700036606.

Bungin, Burhan. 2007. Penelitian Kualitatif: Komunikasi, Ekonomi, Kebijakan Publik, Dan Ilmu Sosial Lainnya. Jakarta: Kencana Prenada Media Group.

Burdah, Ibnu. 2018. "Serpihan-Serpihan Narasi Alternatif." In Literatur Keislaman Generasi Milenial: Transmisi, Apropiasi, Dan Kontestasi, edited by Noorhaidi Hasan, 2nd ed. Yogyakarta: Pascasarjana UIN Sunan Kalijaga Press.

Creswell, John W. 2007. Qualitative Inquiry \& Research Design: Choosing among Five Approaches. London and New Delhi: Sage Publications.

David, Fred R. 2006. Manajemen Strategis. 10th ed. Jakarta: Penerbit Salemba.

Edwards, Martyn. 2012. "Literacy Practies: Using the Literacies for Learning in Further Education Framework to Analyse Literacy Practies on a PostCompulsory Education and Training Teacher Education Programme." Student Engagement and Experience Journal 1 (1): 1-10.

Hasan, Noorhaidi, Suhadi, Munirul Ikhwan, Moch Nur Ichwan, Najib Kailani, Ahmad Rafiq, and Ibnu Burdah. 2018. Literatur Keislaman Generasi Milenial. Edited by Noorhaidi 
Hasan. 2nd ed. Yogyakarta: Pascasarjana UIN Sunan Kalijaga Press.

Ichwan, Moch. Nur. 2018. "Sirkulasi Dan Transmisi Literatur Keislaman: Ketersediaan, Aksesabililtas, Dan Ketersebaran." In Literatur Keislaman Generasi Milenial: Transmisi, Apropiasi, Dan Kontestasi, edited by Noorhaidi Hasan, 2nd ed. Yogyakarta: Pascasarjana UIN Sunan Kalijaga Press.

Ikhwan, Munirul. 2018. "Produksi Wacana Islam(Is) Di Indonesia: Revitalisasi Islam Publik Dan Politik Muslim.” In Literatur Keislaman Generasi Milenial: Transmisi, Apropiasi, Dan Kontestasi., edited by Noorhaidi Hasan, 2nd ed. Yogyakarta: Pascasarjana UIN Sunan Kalijaga Press.

Iswanto, Agus, Moch. Lukluil Maknun, Mustolehudin, Umi Masfiah, Subkhan Ridlo, and Roch. Aris Hidayat. 2019. Praktik Literasi Mahasiswa Universitas Islam Negeri: Tantangan Dan Peluang Literasi Di Era Digital. Jakarta: Litbangdiklat Press.

Jogiyanto. 2005. Sistem Informasi Strategik Untuk Keunggulan Kompetitif. Yogyajarta: Penerbit Andi Offset.

Kailani, Najib. 2018. "Literatur Keislaman Generasi Milenial: Transmisi, Apropiasi, Dan Kontestasi." In Literatur Keislaman Generasi Milenial: Transmisi, Apropiasi, Dan Kontestasi, edited by Noorhaidi Hasan, 2nd ed. Yogyakarta: Pascasarjana UIN Sunan Kalijaga Press.

Kemendikbud, Kementerian Pendidikan dan Kebudayaan. 2016. Pedoman Pelaksanaan Gerakan Nasional Literasi Bangsa. Jakarta: Pusat Pembinaan Badan Pengembangan dan Pembinaan Bahasa Kementerian Pendidikan dan Kebudayaan.

Kooij, Rijnardus A Van. 2007. Menata Karya Nyata: Sumbangan Teologi Praktis Dalam Pencarian Model Pembangunan Jemaat Kontekstual. Jakarta: BPK Gunung Mulia. 
LPM-Solidaritas. 2017. "Materi Musyawarah Anggota (MUSANG) XV LPM Solidaritas.” Surabaya.

Primadesi, Yona. 2018. Dongeng Panjang Literasi Indonesia: Sehimpun Esai. Padang: Kabarita.

Prodi-Sistem-Informasi-UINSA. 2016. "Kurikulum KKNI Prodi Sistem Informasi." Surabaya: Prodi Sistem Informasi UINSA.

Rafiq, Ahmad. 2018. "Dinamika Literatur Islamis Di Ranah Lokal." In Literatur Keislaman Generasi Milenial: Transmisi, Apropiasi, Dan Kontestasi, edited by Noorhaidi Hasan, 2nd ed. Yogyakarta: Pascasarjana UIN Sunan Kalijaga Press.

Rangkuti, Freddy. 2006. Analisis SWOT Teknik Membedah Kasus Bisnis. Jakarta: PT. Gramedia Pustaka Utama.

Rusydiyah, Evi Fatimatur, ed. 2017. Pedoman KKN Literasi Dengan Pendekatan ABCD (Asset Based CommunityDriven Development) UIN Suan Ampel Surabaya. Surabaya: Lembaga Penelitian dan Pengabdian Masyarakat UIN Sunan Ampel Surabaya.

Suhadi. 2018. "Menu Bacaan Pendidikan Agama Islam Di SMA Dan Perguruan Tinggi." In Literatur Keislaman Generasi Milenial: Transmisi, Apropiasi, Dan Kontestasi., edited by Noorhaidi Hasan, 2nd ed. Yogyakarta: Pascasarjana UIN Sunan Kalijaga Press.

Suwarto, Dyna Herlina, ed. 2018. Gerakan Literasi Media Di Indonesia. Yogyakarta.

UINSA. 2015. "Profil UIN Surabaya." 2015. http:// www.uinsby. ac.id/id.

Informan:

Dr. Fatoni Hasyim, Ketua LP2M UINSA (16 Mei 2018)

Dr. Evi Fatimatur Rusydiyah, Dosen dan Kepala Lab Fak. Tarbiyah UINSA (17 Mei 2018) 
Umi Rodliyah, Kabag Verifikasi Perpustakaan UINS (17 Mei 2018)

Wiji Agustin Sasmita, Ketua Pers Solidaritas UINSA (21 Mei 2018)

Riski Ramdhani, Anggota Pers Solidaritas UINSA (21 Mei 2018)

Dr. M. Thohir, Bagian Pengembangan Mahasiswa LPM UINSA (22 Mei 2018) 